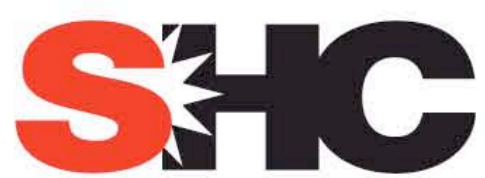

SOLAR HEATING \& COOLING PROGRAMME INTERNATIONAL ENERGY AGENCY
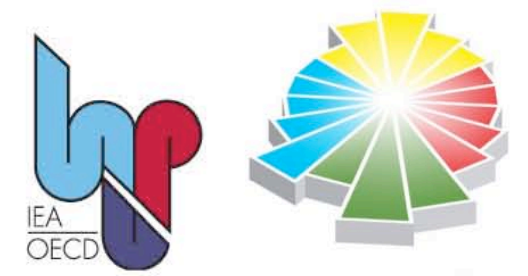

SOLAR + HEAT PUMP

\title{
Newsletters issued by IEA Task 44 / Annex 38 from 2010 to 2013
}

\section{A technical report of subtask D - Report D2}

Date: 21.10.2013

\section{By Matteo D'Antoni}

${ }^{1}$ Eurac Research, Institute for Renewable Energy

Viale Druso 1

I - 39100 Bolzano

Phone: $\quad+390471055614$

Fax: $\quad+390471055699$

e-mail: matteo.dantoni@eurac.edu 


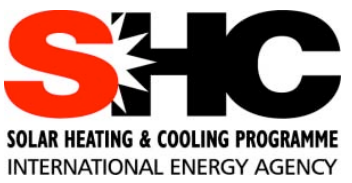

\section{IEA Solar Heating and Cooling Programme}

The Solar Heating and Cooling Programme was founded in 1977 as one of the first multilateral technology initiatives ("Implementing Agreements") of the International Energy Agency. Its mission is "to enhance collective knowledge and application of solar heating and cooling through international collaboration to reach the goal set in the vision of solar thermal energy meeting $50 \%$ of low temperature heating and cooling demand by 2050.

The member countries of the Programme collaborate on projects (referred to as "Tasks") in the field of research, development, demonstration (RD\&D), and test methods for solar thermal energy and solar buildings.

A total of 52 such projects have been initiated to-date, 39 of which have been completed. Research topics include:

A Solar Space Heating and Water Heating (Tasks 14, 19, 26, 44)

A Solar Cooling (Tasks 25, 38, 48)

A Solar Heat or Industrial or Agricultural Processes (Tasks 29, 33, 49)

A Solar District Heating (Tasks 7, 45)

A Solar Buildings/Architecture/Urban Planning (Tasks 8, 11, 12, 13, 20, 22, 23, 28, 37, 40, 41, $47,51,52)$

A Solar Thermal \& PV (Tasks 16, 35)

A Daylighting/Lighting (Tasks 21,31,50)

A Materials/Components for Solar Heating and Cooling (Tasks 2, 3, 6, 10, 18, 27, 39)

A Standards, Certification, and Test Methods (Tasks 14, 24, 34, 43)

A Resource Assessment (Tasks 1, 4, 5, 9, 17, 36, 46)

A Storage of Solar Heat (Tasks 7, 32, 42)

In addition to the project work, there are special activities:

$>\quad$ SHC International Conference on Solar Heating and Cooling for Buildings and Industry

$>\quad$ Solar Heat Worldwide - annual statistics publication

$>\quad$ Memorandum of Understanding with solar thermal trade organizations

$>\quad$ Workshops and conferences

\section{Country Members}

Australia

Austria

Belgium

China

Canada

Denmark

European Commission

\section{Sponsor Members}

ECI

Further information:

$\begin{array}{lc}\text { Germany } & \text { Portugal } \\ \text { Finland } & \text { Singapore } \\ \text { France } & \text { South Africa } \\ \text { Italy } & \text { Spain } \\ \text { Mexico } & \text { Sweden } \\ \text { Netherlands } & \text { Switzerland } \\ \text { Norway } & \text { United States }\end{array}$

ECREEE

RCREEE 
For up to date information on the IEA SHC work, including many free publications, please visit www.iea-shc.org. 
Current Tasks \& Working Group:

Task $36 \quad$ Solar Resource Knowledge Management

Task $39 \quad$ Polymeric Materials for Solar Thermal Applications

Task $40 \quad$ Towards Net Zero Energy Solar Buildings

Task $41 \quad$ Solar Energy and Architecture

Task $42 \quad$ Compact Thermal Energy Storage

Task $43 \quad$ Solar Rating and Certification Procedures

Task $44 \quad$ Solar and Heat Pump Systems

Task $45 \quad$ Large Systems: Solar Heating/Cooling Systems, Seasonal Storages, Heat Pumps

Task $46 \quad$ Solar Resource Assessment and Forecasting

Task $47 \quad$ Renovation of Non-Residential Buildings Towards Sustainable Standards

Task $48 \quad$ Quality Assurance and Support Measures for Solar Cooling

Task $49 \quad$ Solar Process Heat for Production and Advanced Applications

Completed Tasks:

Task $1 \quad$ Investigation of the Performance of Solar Heating and Cooling Systems

Task $2 \quad$ Coordination of Solar Heating and Cooling $R \& D$

Task $3 \quad$ Performance Testing of Solar Collectors

Task $4 \quad$ Development of an Insolation Handbook and Instrument Package

Task 5

Task 6

Task 7

Task 8

Task 9

Task 10

Task 11

Task 12

Task 13

Task 14

Task 16

Task 17

Task 18

Task 19

Task 20

Task 21

Task 22

Task 23

Task 24

Task 25

Task 26

Task 27

Task 28

Task 29

Task 31

Use of Existing Meteorological Information for Solar Energy Application

Performance of Solar Systems Using Evacuated Collectors

Central Solar Heating Plants with Seasonal Storage

Passive and Hybrid Solar Low Energy Buildings

Solar Radiation and Pyranometry Studies

Solar Materials $R \& D$

Passive and Hybrid Solar Commercial Buildings

Building Energy Analysis and Design Tools for Solar Applications

Advanced Solar Low Energy Buildings

Advanced Active Solar Energy Systems

Photovoltaics in Buildings

Measuring and Modeling Spectral Radiation

Advanced Glazing and Associated Materials for Solar and Building Applications

Solar Air Systems

Solar Energy in Building Renovation

Daylight in Buildings

Building Energy Analysis Tools

Optimization of Solar Energy Use in Large Buildings

Solar Procurement

Solar Assisted Air Conditioning of Buildings

Solar Combisystems

Performance of Solar Facade Components

Solar Sustainable Housing

Solar Crop Drying

Daylighting Buildings in the 21st Century

Task 32

Task 33

Task 34

Task 35

Advanced Storage Concepts for Solar and Low Energy Buildings

Solar Heat for Industrial Processes

Testing and Validation of Building Energy Simulation Tools

PV/Thermal Solar Systems

Task $37 \quad$ Advanced Housing Renovation with Solar \& Conservation

Task 38

Solar Thermal Cooling and Air Conditioning

Completed Working Groups:

CSHPSS; ISOLDE; Materials in Solar Thermal Collectors; Evaluation of Task 13 Houses; Daylight Research 


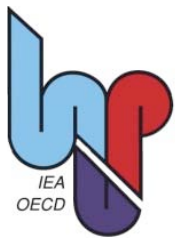

\section{IEA Heat Pump Programme}

This project was carried out within the Solar Heating and Cooling Programme and also within the Heat Pump Programme, HPP which is an Implementing agreement within the International Energy Agency, IEA. This project is called Task 44 in the Solar Heating and Cooling Programme and Annex 38 in the Heat pump Programme.

The Implementing Agreement for a Programme of Research, Development, Demonstration and Promotion of Heat Pumping Technologies (IA) forms the legal basis for the IEA Heat Pump Programme. Signatories of the IA are either governments or organizations designated by their respective governments to conduct programmes in the field of energy conservation.

Under the IA collaborative tasks or "Annexes" in the field of heat pumps are undertaken. These tasks are conducted on a cost-sharing and/or task-sharing basis by the participating countries. An Annex is in general coordinated by one country which acts as the Operating Agent (manager). Annexes have specific topics and work plans and operate for a specified period, usually several years. The objectives vary from information exchange to the development and implementation of technology. This report presents the results of one Annex. The Programme is governed by an Executive Committee, which monitors existing projects and identifies new areas where collaborative effort may be beneficial.

\section{The IEA Heat Pump Centre}

A central role within the IEA Heat Pump Programme is played by the IEA Heat Pump Centre (HPC). Consistent with the overall objective of the IA the HPC seeks to advance and disseminate knowledge about heat pumps, and promote their use wherever appropriate. Activities of the HPC include the production of a quarterly newsletter and the webpage, the organization of workshops, an inquiry service and a promotion programme. The HPC also publishes selected results from other Annexes, and this publication is one result of this activity.

For further information about the IEA Heat Pump Programme and for inquiries on heat pump issues in general contact the IEA Heat Pump Centre at the following address:

IEA Heat Pump Centre

Box 857

SE-501 15 BORÅS

Sweden

Phone: +4610165512

Fax: +4633131979

Visit the Heat Pump Programme website - http://www.heatpumpcentre.org/ - to find more publications and to learn about the HPP Programme.

Legal Notice Neither the IEA Heat Pump Centre nor the SHC Programme nor any person acting on their behalf: (a) makes any warranty or representation, express or implied, with respect to the information contained in this report; or (b) assumes liabilities with respect to the use of, or damages, resulting from the use of this information. Reference herein to any specific commercial product, process, or service by trade name, trademark, manufacturer, or otherwise, does not necessarily constitute or imply its endorsement recommendation or favouring. The views and opinions of authors expressed herein do not necessarily state or reflect those of the IEA Programmes, or any of its employees. The information herein is presented in the authors' own words. 


\section{Contents}

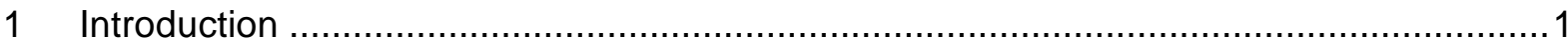

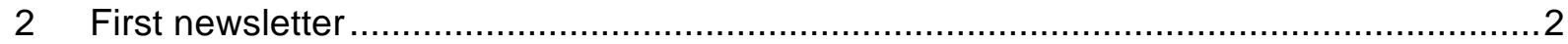

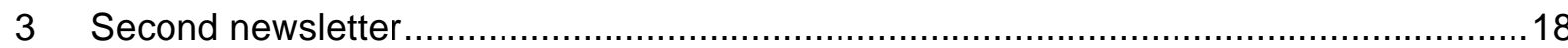

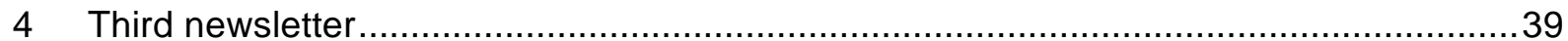




\section{Introduction}

This deliverable collects all newsletter issues produced by Subtask D within IEA Task 44 / Annex 38 (T44A38). The motivation of these newsletters is to communicate to the industry and the research community important developments and findings achieved within T44A38. The first issue has aimed to present the objectives, the structure and the activities, as well as the participants of the project. The second issue has focused on the classification of Solar plus Heat Pump (SHP) systems according different criteria (e.g. heat pump evaporator sources, building load covered, ...) and the presentation of a unified energy flow chart for the analysis of SHP systems. The third newsletter has presented monitoring results of different SHP concepts under different boundary conditions (location and building loads).

The newsletters have been posted in project webpage (http://task44.iea-shc.org), distributed in fairs and events on solar thermal and heat pump topics and linked to the project Wikipedia page. 


\section{First newsletter}

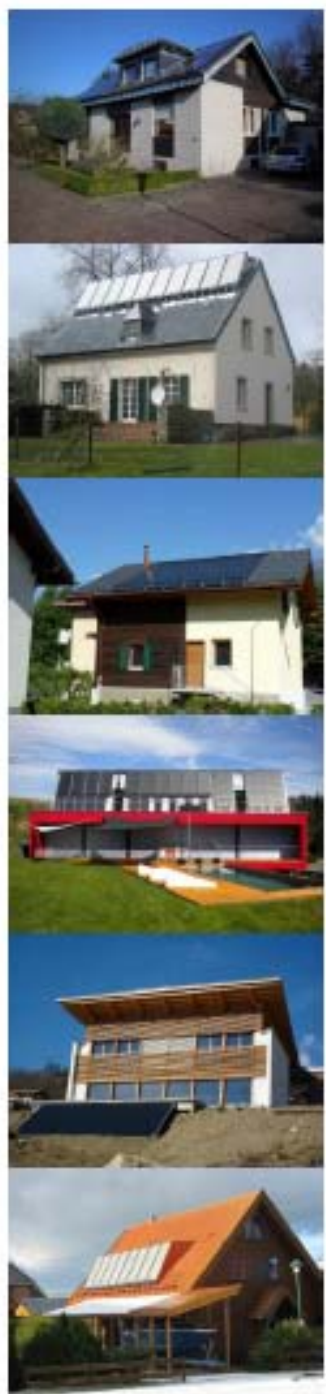

IEA - SHC Task 44 / Annex 38 Solar and Heat Pump Systems

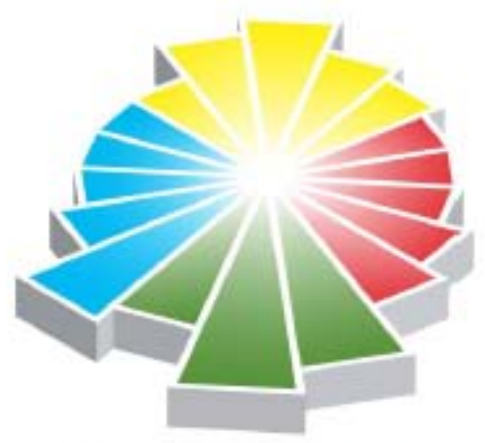

Industry Newsletter

First issue

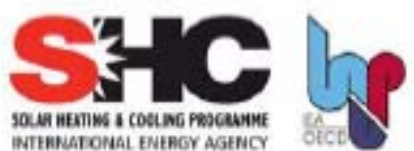




\title{
Industry newsletter
}

First issue, 10-2011

\section{IEA - SHC Task 44 / Annex 38 \\ Solar and Heat Pump Systems}

\author{
Elaborated by: \\ M. D'Antoni, W. Sparber \\ EURAC Research
}

This newsletter presents the status of the work of the SHC Task 44 / HPP Annex 38 or T44A38 work. The solar industry and the heat pump industry are the primary targets. The content reflects the activities along the course of the work and not necessarily the final conclusions that will be published in all deliverables at the end of the work duration (December 2013).

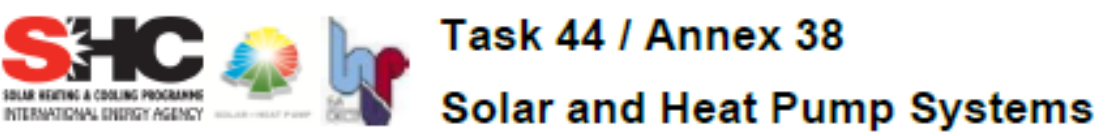




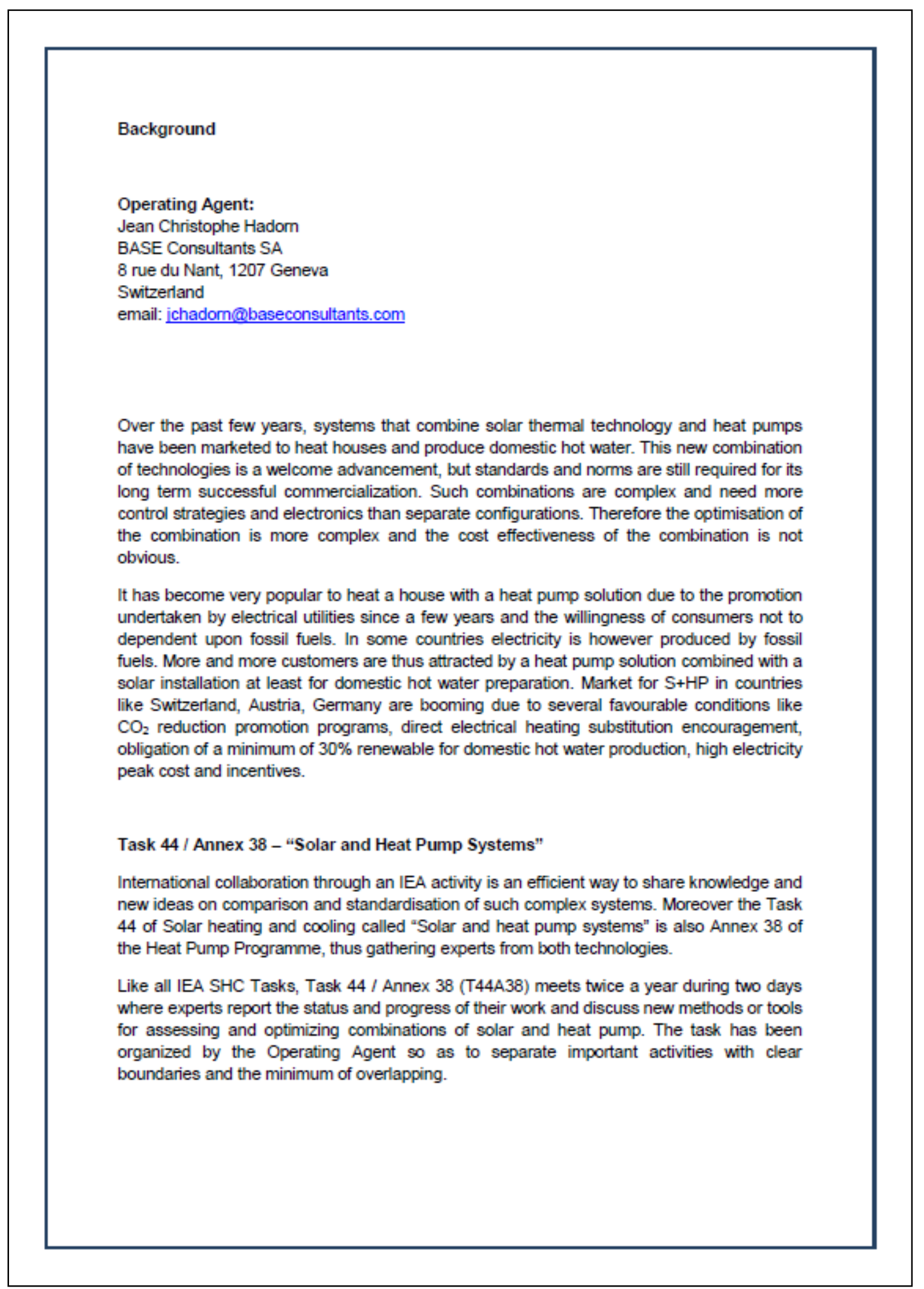




\section{Task Objectives}

The objective of this Task is the assessment of performances and relevance of combined systems using solar thermal and heat pumps, to provide common definition of performances of such systems and to contribute to successful market penetration of these new systems.

Other objectives are needed to reach the main one where international collaboration is definitively needed to make it possible within a 4 years framework, mainly:

- surveying the possible generic combinations;

- defining performance figures of a combined solar and heat pump solution;

- defining assessment and test methods of such systems;

- analysing monitored data on such systems;

- developing component models or integrating existing ones into a system model;

- simulating various systems under common conditions;

- providing guidelines of good practice to the market and stakeholder;

- providing authorities with relevant information on the interest of such systems;

- staying close to the market and bringing independent information and knowledge to the actors on this market along the duration of the Task.

The scope of the Task considers solar thermal systems in combination with heat pumps, applied for the supply of domestic hot water and heating in family houses.

\section{Duration of Task 44 / Annex 38}

Task 44 / Annex 38 started in January 2010 and will end in December 2013. A number of deliverables will be available from time to time on the T44/A38 web site:

http://www.iea-shc.orq/task44l.
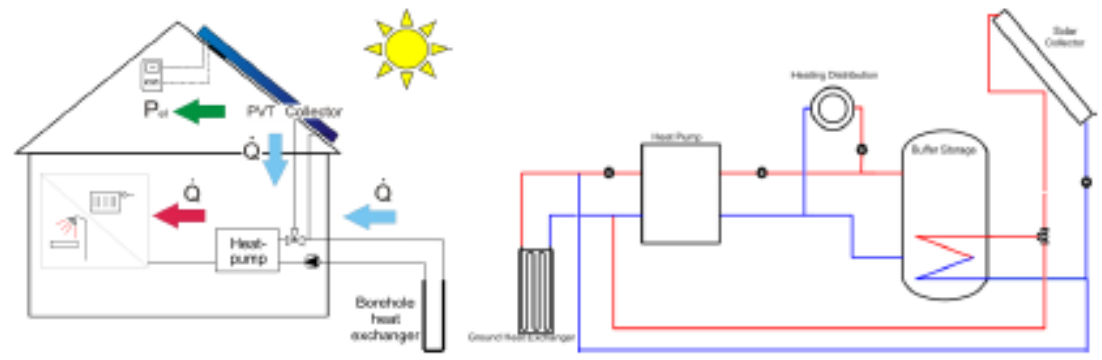

Figure 1 and 2: S+HP system: Example of a system including PV-T collectors and ground heat exchanger coupled with a water-to-water heat pump (source: ISFH and Fraunhofer ISE). 


\section{Subtasks}

The work in this T44A38 is divided into four Subtasks:

- Subtask A: Overview of solutions (existing, new) and generic systems, led by Sebastian Herkel from Fraunhofer ISE of Stuttgart, Germany,

- Subtask B: Performance assessment, led by Ivan Malenkovic from the Austrian Institute of Technology (AIT);

- Subtask C: Modelling and simulation, led by Michel Haller from the SPF in Rapperswil, Switzerland;

- Subtask D: Dissemination and market support, led by Wolfram Sparber form the EURAC Research centre in Bolzano, Italy.

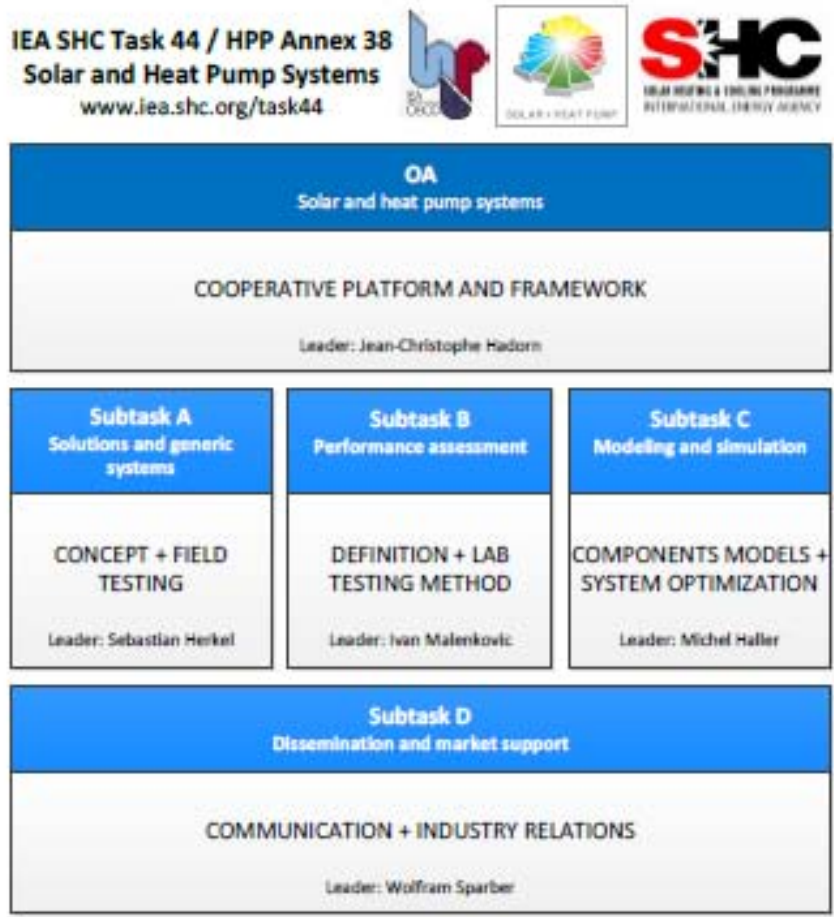




\section{Subtask A:}

\section{Solutions and generic systems}

\section{Subtask Leader:}

Sebastian Herkel

Fraunhofer ISE, Hiedenhofstrasse 2, 79110 Freiburg

GERMANY

email: sebastian.herkel@ise.fraunhofer.de

The objective of Subtask $\mathrm{A}$ is to collect, create and disseminate information about the current and future solutions for combining solar heat pump systems. Both heat pumps and solar thermal collectors gained high popularity in the European market, as it can be seen in Figure 3. The similarity of these trends is striking, though unfortunately, it remains unknown to what extent the components were installed in combined systems.

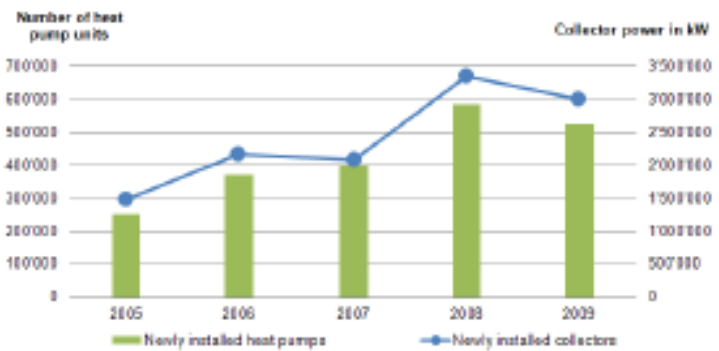

Figure 3: Market development of solar collectors (EU27+CH, data from ESTIF) and heat pumps (AT, CH, DE, FI, FR, IT, NO, SE, UK data from EHPA) (elaborated by Fraunhofer ISE).

A review of market-available systems was started within Subtask A in 2010. The aim is to provide a more detailed description for each system, including specifications of the main components, hydraulic schemes and market availability. Until today, 75 distinguishable products were found. By far most of them are offered by German or Austrian manufacturers, numerous systems also by Danish, French, Swiss and Swedish companies. Structured by the source of the heat pump used within these systems, the result appears as follows:

- 34 air,

- 34 ground

- 2 water;

- 5 waste heat. 


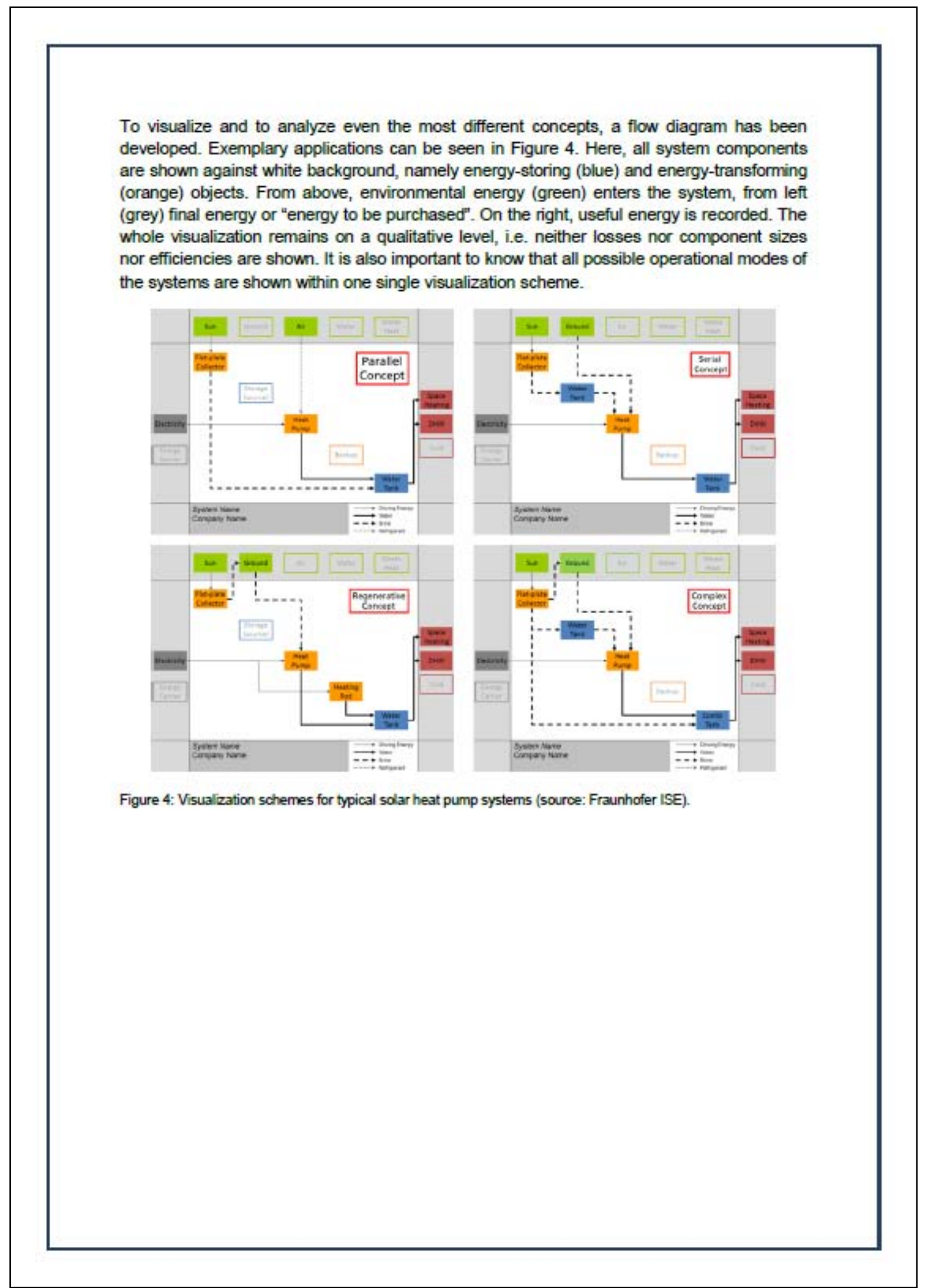




\section{Subtask B:}

\section{Performance assessment}

\section{Subtask Leader:}

Ivan Malenkovic

AIT Austrian Institute of Technology, Giefinggasse 2, 1210 Vienna

AUSTRIA

email: ivan.malenkovic@ait.ac.at

The objective of this subtask is to reach a common definition on performance figures for solar heat pump systems and define procedures for their assessment. This is an important goal since this technology presently lacks standardised quality assurance methods - a fact that can have a negative impact on the future market development. The results of the subtask should finally lead to a pre-normative definition of performance assessment methods for solar heat pump systems. The work is coordinated with a number of on-going activities concerning other, both heat pump and solar thermal applications and should provide a transparent basis for technology comparisons both on the economic and ecological levels.

The output of the subtask should be used by the industry to communicate the performance of the systems they promote. To facilitate this, the first step was to propose a systematic approach regarding the definition of performance figures, Figure 5.

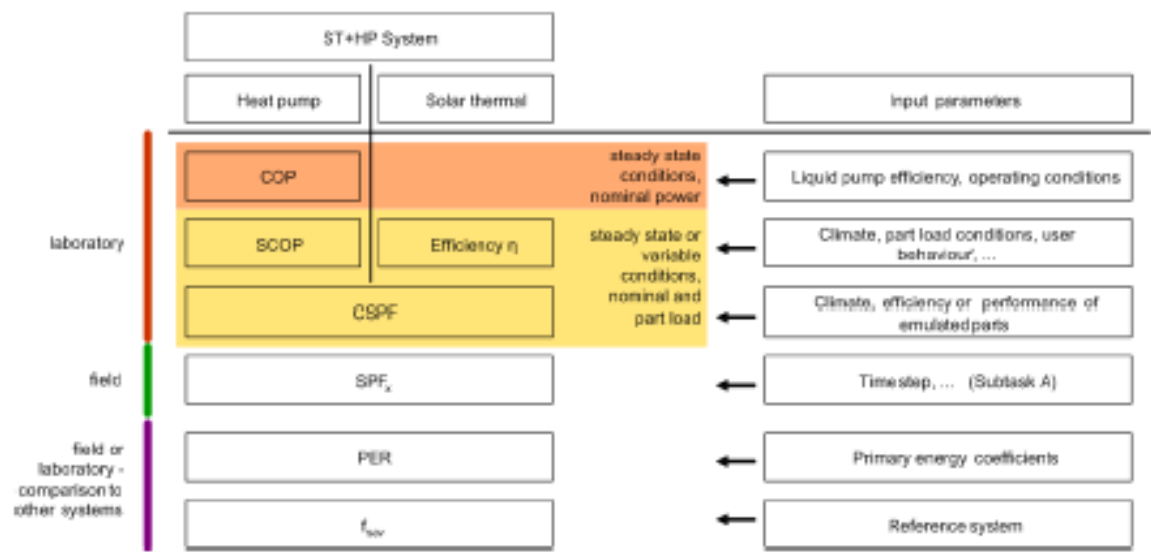

Figure 5: Proposal for a systematic approach to the definition of performance figures for solar heat pump systems (source: AIT). 
Based on an analysis of currently available standards for solar thermal and heat pump technologies, proposed approach includes clear nomenclature, definition of system boundaries and type of boundary conditions for the most important performance figures.

A survey of existing solar heat pump systems yielded a variety of different configurations. It is therefore necessary for a widely applicable definition of performance figures to create a generic system which covers all available system configurations.

In Figure 4, the elaborated generic system with an example of three system boundaries for the performance assessment of solar heat pump systems and their subsystems is shown. When choosing the boundaries and defining the performance figures, the following aims were considered:

- Analysis of the system performance for development and optimisation;

- Comparison of systems within the solar heat pump technology for quality assurance;

- Comparison of solar heat pump systems with other technologies regarding economic and ecological aspects.

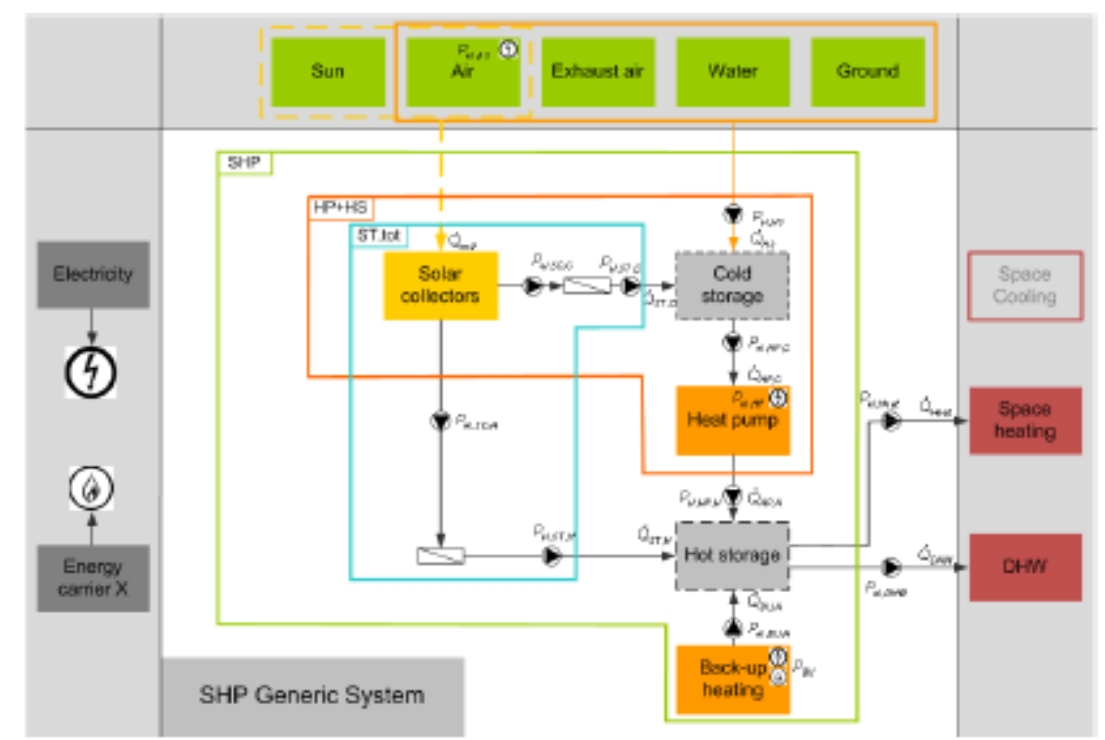

Figure 6: Proposal for a systematic approach to the definition of performance figures for solar heat pump systems (source: AIT)

Following the definition of performance figures, test methods as a basis for future quality assurance tools will be developed. Technical reports on measurement results from laboratory tests on different systems will be a part of the subtask output.

Finally, the requirements for a quality label, comparable to existing marketing tools for solar thermal or heat pump technologies, will be discussed and work on needed standards initiated within respective standardisation committees (e.g. CEN or ISO). 


\section{Subtask C:}

\section{Modeling and simulation}

\section{Subtask Leader:}

Michel Haller

Institut für Solartechnik SPF, University of Applied Science Rapperswil HSR

Oberseestrasse 10, 8640 Rapperswil

SWITZERLAND

email: michel.haller@solarenergy.ch

For the evaluation and optimization of systems, detailed component and system models are needed. In Subtask $C$, those modeling tools for components and complete generic systems are compiled, used and compared. Different partners are carrying out simulations and sensitivity analysis on systems which are then used to identify important and less important features for different system configurations. Furthermore, the thermodynamics of heat pump processes that involve more than one heat source are analyzed. Based on the results of this subtask, accurate performance simulation and sizing of systems will be possible.

A comparison of energy performance simulation results for different systems is only possible if the same boundary conditions for the domestic hot water demand and the building heat load were applied. Therefore, common boundary conditions have been defined and implemented on three different simulation platforms that are used within T44A38 (TRNSYS, Matlab-Simulink and IDA-ICE).

A collection and documentation of state of the art simulation models for the different components in solar \& heat pump systems has been elaborated. These collections include models for solar thermal collectors (flat plate, vacuum tube and uncovered), heat pumps (airsource, ground source / brine source), ground heat exchange (vertical boreholes as well as horizontal collectors) and heat storage (sensible and latent).
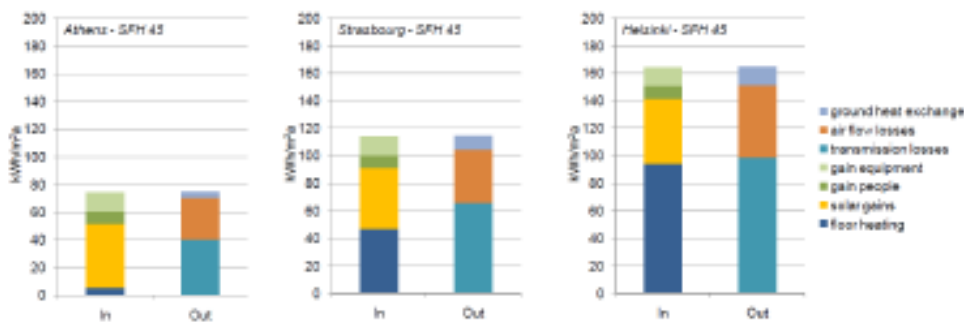

Figure 7: Building energy balances of a Single Family building with an annual heating demand of 45 $\mathrm{kWh} /\left(\mathrm{m}^{2}\right.$ year) for Strasbourg climate - SFH 45 - at three different reference location. 


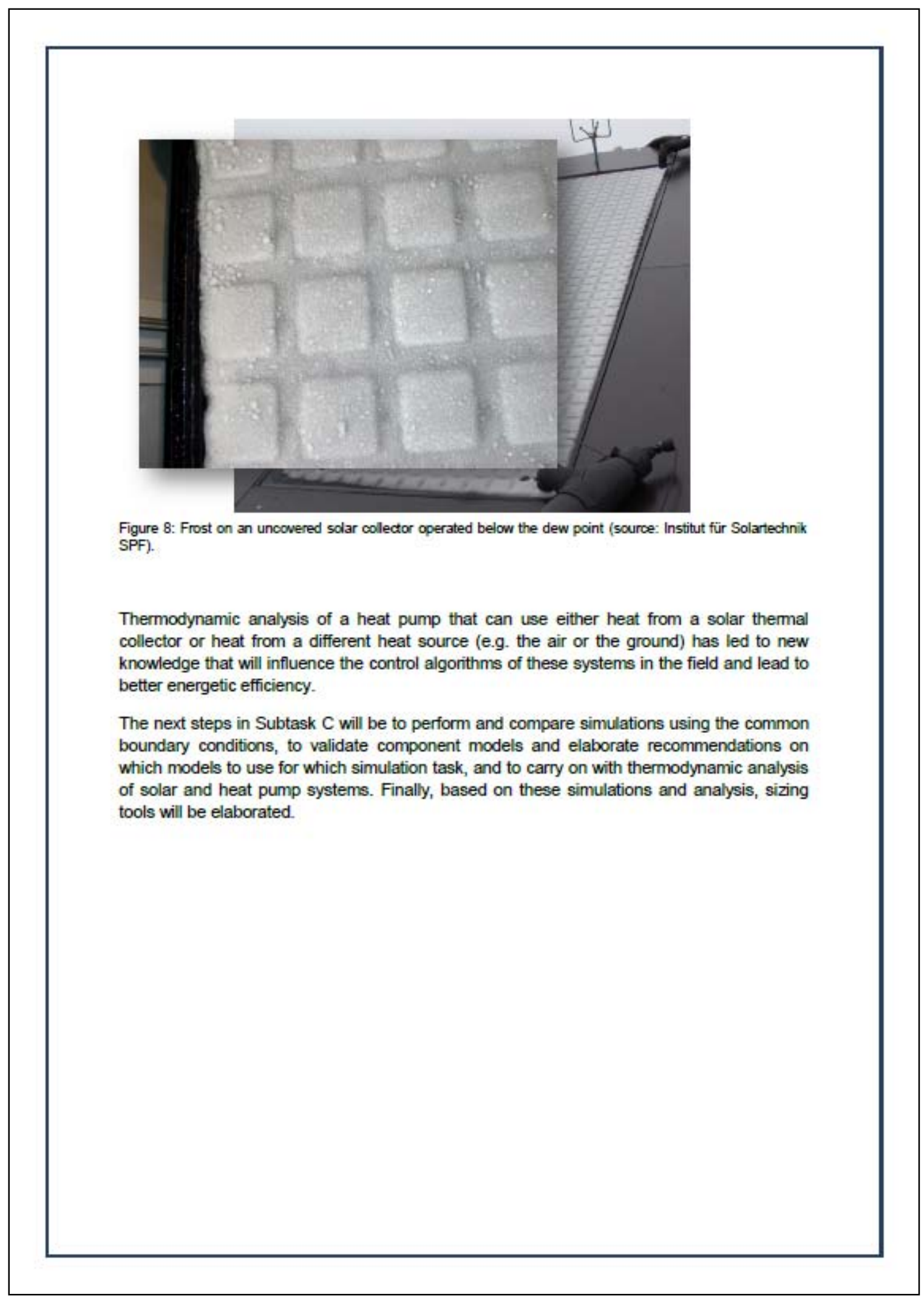




\title{
Subtask D:
}

\section{Dissemination and market support}

\author{
Subtask Leader: \\ Wolfram Sparber \\ EURAC Research, Viale Druso 1, 39100 Bolzano \\ ITALY \\ email: wolfram.sparber@eurac.edu
}

The objective of this subtask is to provide information on on-going R\&D activities to the scientific community, industrial actors and to the public during the course of the Task so that the value added created by the participants can be transferred as fast as possible to a growing market.

The communication of the running activities is organized via different communication channels. An important channel is the homepage of T44A38 where all main information and results are collected. Within the homepage it has been decided to collect not only material strictly from the task, but as well on topics which are related to the task. Therefore there are included the links to research and industry actors working in the field as well as links to other R\&D projects researching within the topic. Furthermore within the download area scientific publications are listed which Task participants have published on international scientific conferences on solar and heat pump systems.

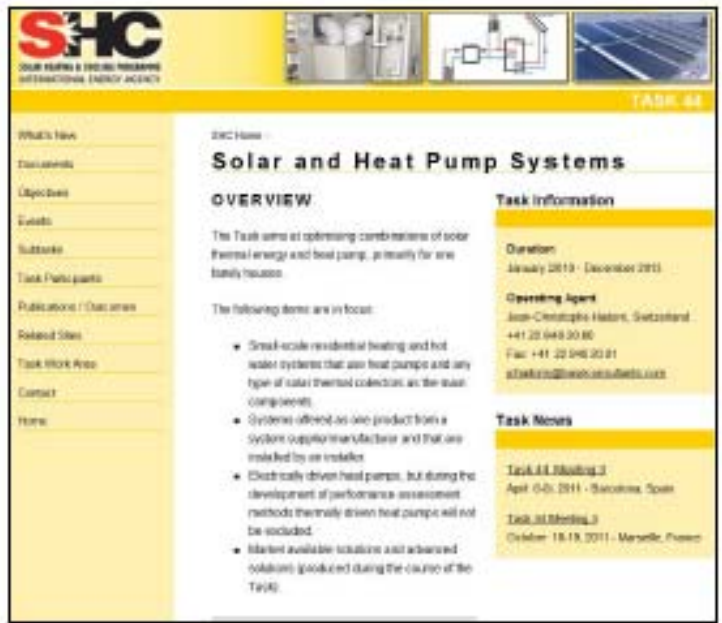

Figure 9: view of the Task 44 / Annex 38 web page (wwwiea-shcorg/task44) 


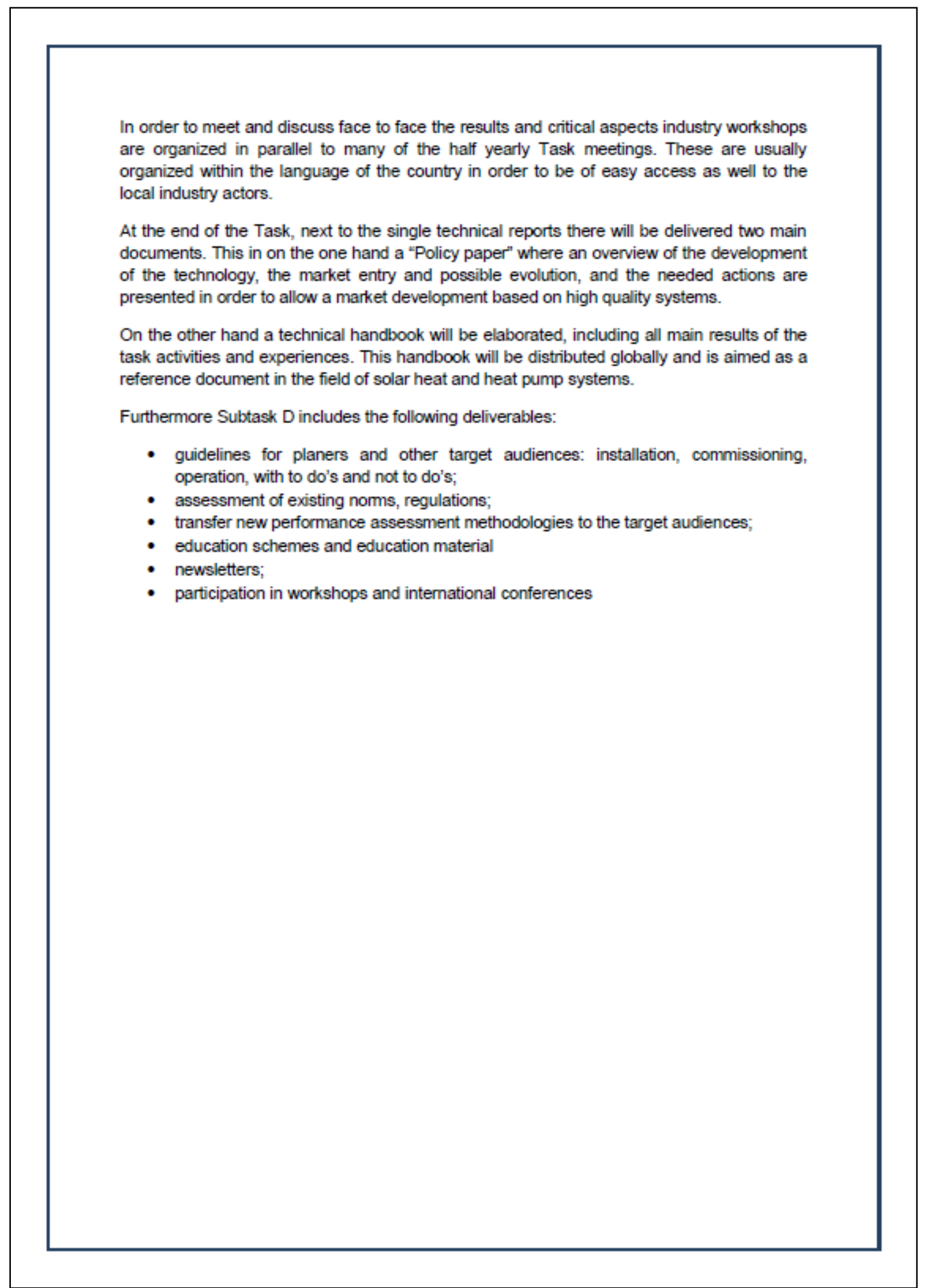


Recent publications on the topic:

[1] Bertram, E., Stegmann, M., Kundmüller, K. \& Rosinski, C., 2011, "Wärmepumpensysteme mit unabgedeckten photovoltaisch- termischen Kollektoren", OTTI Solarthermie PVT, Ulm, Germany.

[2] Bertram, E., Glembin, J., Scheuren, J. \& Rockendorf, G., 2010, "Condensation heat gains on unglazed solar collectors in heat pump systems". Eurosun Conference, Graz, Austria.

[3] Bertram, E., Stegmann, M., Scheuren, J., Rosinski, C. \& Kundmüller, K., 2010, "Unglazed photovoltaic thermal collectors in heat pump systems". Eurosun Conference, Graz, Austria.

[4] Bertram, E., Glembin, J., Scheuren, J., Rockendorf, G. \& Zienterra, G., 2008, "Unglazed solar collectors in heat pumps systems: measurement, simulation and dimensioning". Eurosun Conference, Lisbon, Portugal.

[5] Bertram, E. Glembin, J., Scheuren, J. \& Zienterra, G., 2009, "Soil regeneration by unglazed solar collectors in heat pump systems". ISES Solar World Congress, Johannesburg, South Africa.

[6] Bettoni, M., D'Antoni, M. \& Fedrizzi, R., 2011. "Progettazione e analisi numerica di un quadro di controllo standardizzato per applicazione Solar Combi+ di piccola taglia". $48^{\circ}$ Convegno Internazionale AiCARR, Baveno, Italy.

[7] Carbonell, D., Cadafalch, J. \& Consul, R., 2011. "A transient model for radiant heating and cooling terminal heat exchangers applied to radiant floors and ceiling panels". ISES Solar World Congress, Kassel, Germany.

[8] Citherlet, S., Bony, J. \& Nguyen, B., 2008, Sol-Pac. Analyse des performances du couplage d'une pompe à chaleur avec une installation solaire thermique pour la renovation. Heute Ecole d'Ingénierie et de Gestion du Canton de Vaud (HEIG-VD), Yverdon-les-Bains, Switzerland.

[9] D'Antoni, M., Bettoni, D., Fedrizzi, R. \& Sparber, W., 2011, "Parametric analysis of a novel Solar Combi+ configuration for commercialization". $4^{\text {th }}$ International Conference Solar Air-Conditioning, Lamaka, Cyprus.

[10] Frank, E., Haller, M.Y., Herkel, S. \& Ruschenburg, J., 2010, "Systematic classification of combined solar thermal and heat pump systems". Eurosun Conference, Graz, Austria.

[11] Haller, M.Y. \& Frank, E., 2011, "Steigert die Nutzung von Solarkollektoren als Wärmequelle für Wärmepumpen die System-Arbeitzahl?" 21. Symposium Thermische Solarenergie, Bad Staffelstein, Germany.

[12] Haller, M.Y., Frank, E., Trinkl, C. \& Zörner, W., 2010, "Systematische Gliederung der Systemkombination von solarthermischen Anlagen mit Wämepumpen". 20. Symposium Thermische Solarenergie, Bad Staffelstein, Germany. 


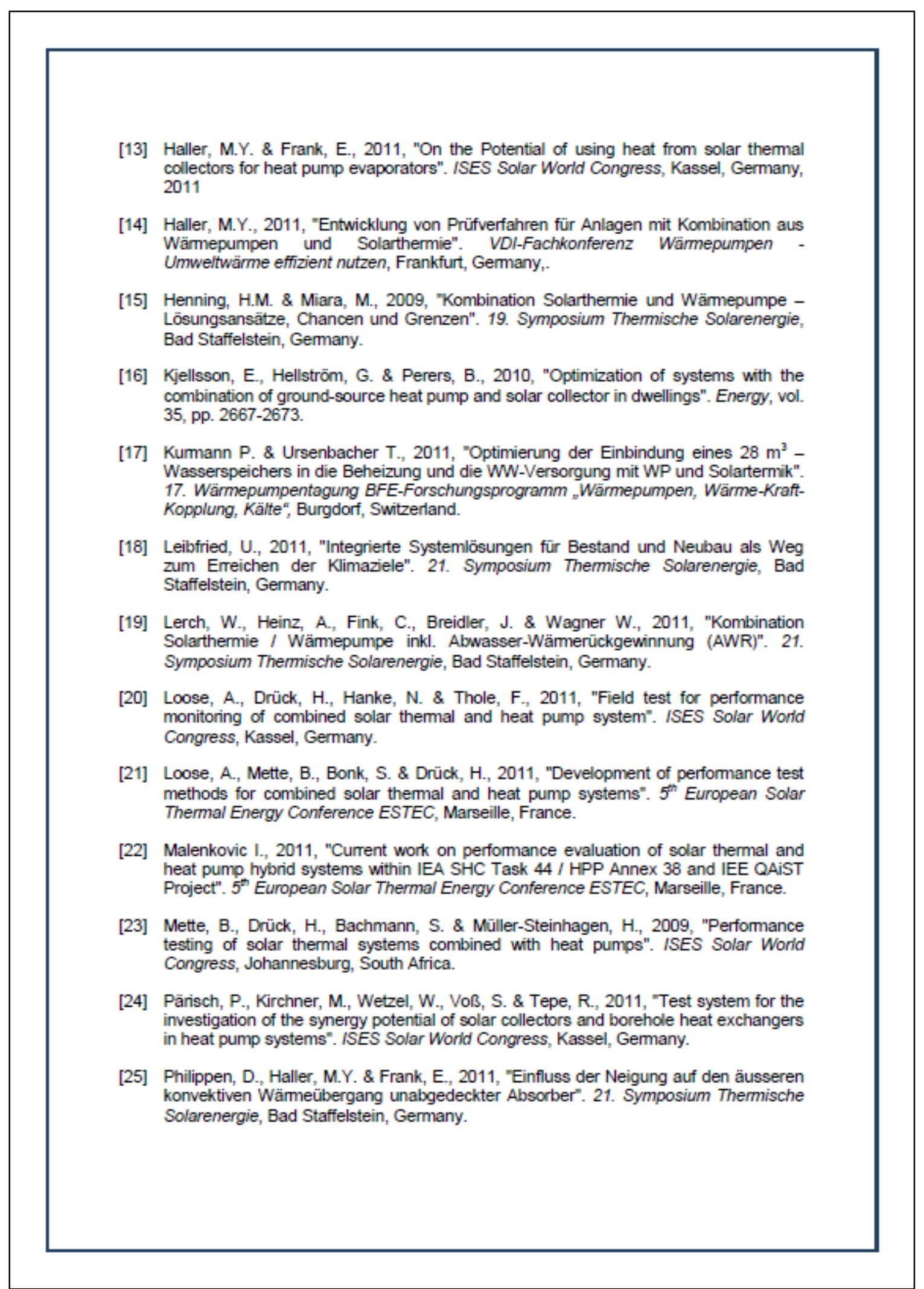




\section{Second newsletter}



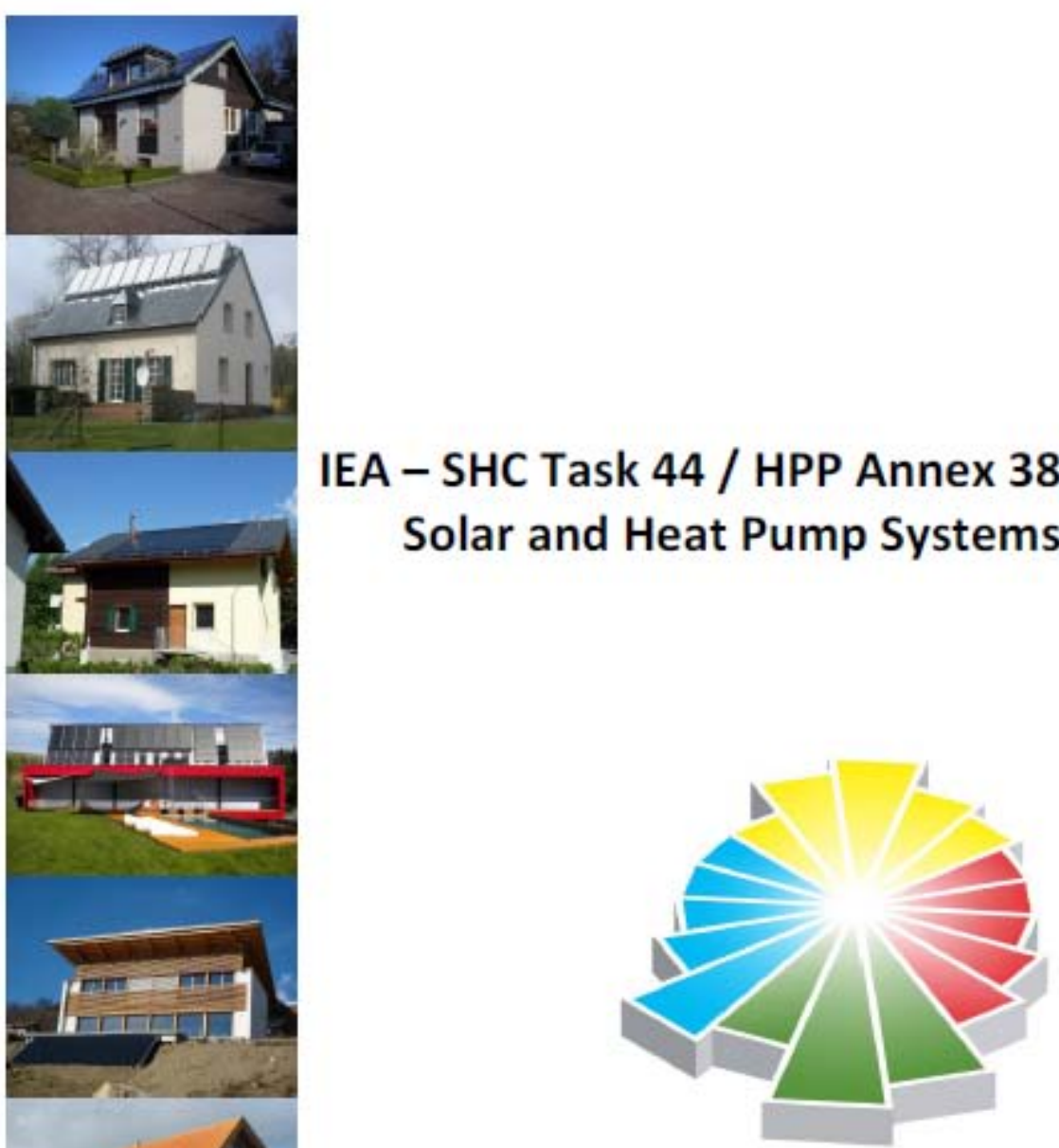

Industry Newsletter

Second issue

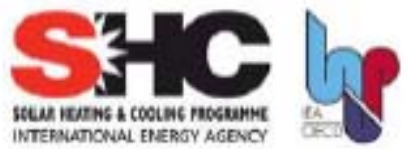




\title{
Industry newsletter
}

Second issue, 6-2012

\section{IEA - SHC Task 44 / HPP Annex 38 \\ Solar and Heat Pump Systems}

\author{
Elaborated by: \\ M. D'Antoni, R. Fedrizzi, W. Sparber \\ EURAC Research
}

This newsletter presents the effort made in classifying Solar and Heat Pumps systems made by Task 44 / Annex 38. A uniform SHP system representation has been presented and a guide line in developing it is shown. This energy flow chart can be applied to any other space heating or DHW generation systems and a direct comparison can be derived. Finally, the framework for the performance figure calculation is presented.

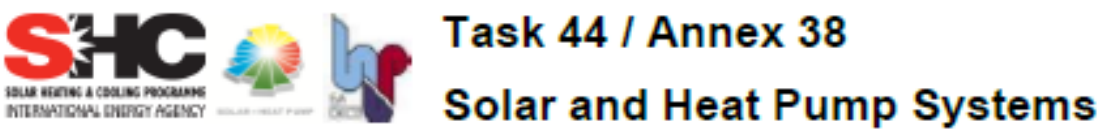




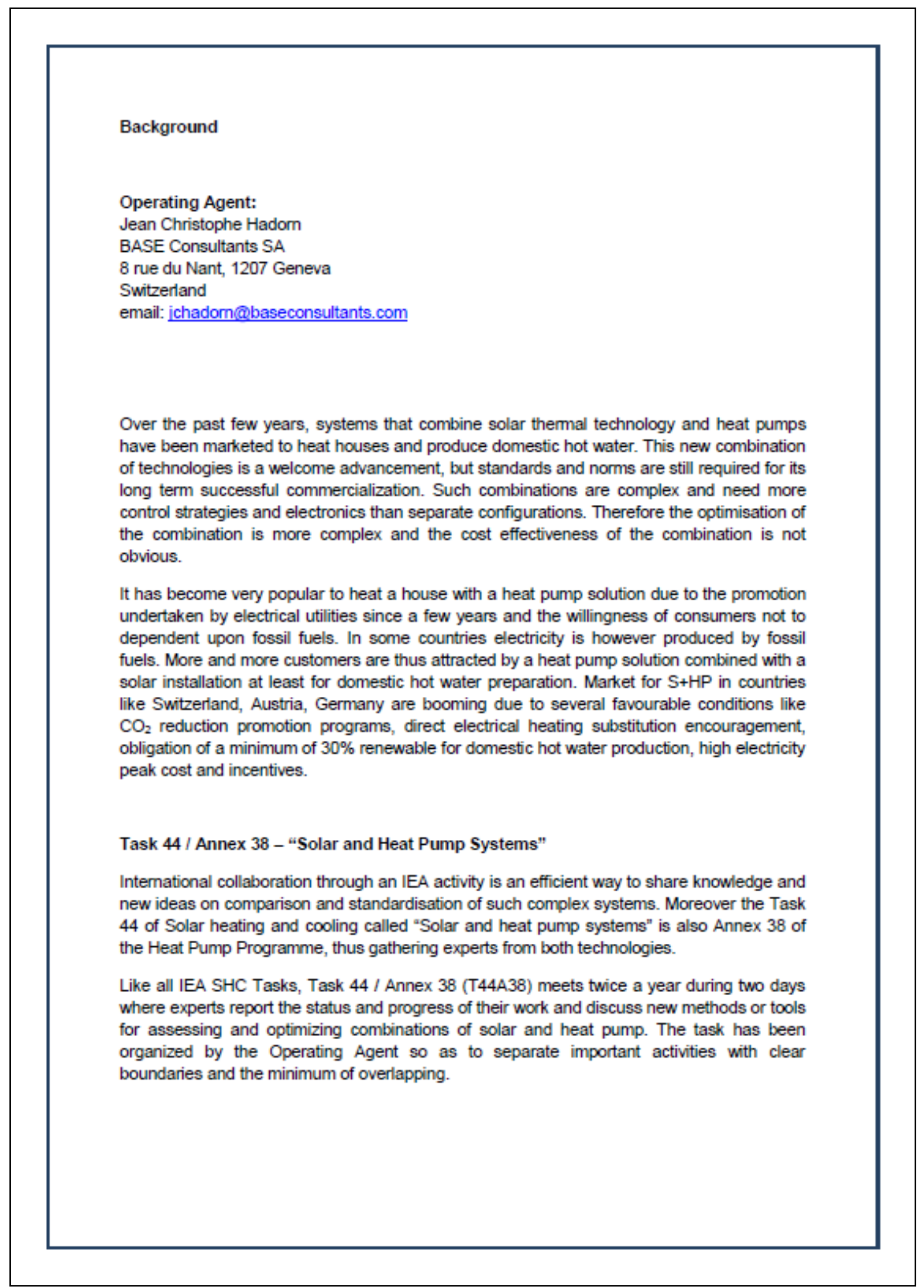




\section{Task Objectives}

The objective of this Task is the assessment of performances and relevance of combined systems using solar thermal and heat pumps, to provide common definition of performances of such systems and to contribute to successful market penetration of these new systems.

Other objectives are needed to reach the main one where international collaboration is definitively needed to make it possible within a 4 years framework, mainly:

- surveying the possible generic combinations;

- defining performance figures of a combined solar and heat pump solution;

- defining assessment and test methods of such systems;

- analysing monitored data on such systems;

- developing component models or integrating existing ones into a system model;

- simulating various systems under common conditions;

- providing guidelines of good practice to the market and stakeholder;

- providing authorities with relevant information on the interest of such systems;

- staying close to the market and bringing independent information and knowledge to the actors on this market along the duration of the Task.

The scope of the Task considers solar thermal systems in combination with heat pumps, applied for the supply of domestic hot water and heating in family houses.

\section{Duration of Task 44 / Annex 38}

Task 44 / Annex 38 started in January 2010 and will end in December 2013. A number of deliverables will be available from time to time on the T44/A38 web site:

http://www.iea-shc.org/task44/.

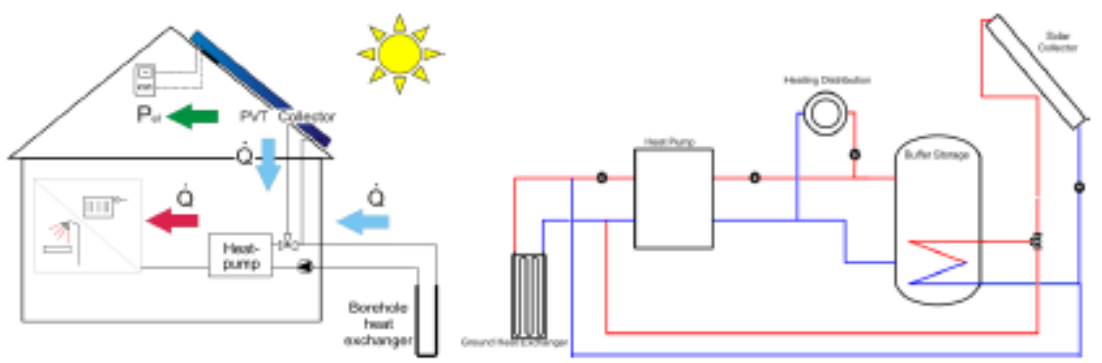

Figure 1 and 2: S+HP system: Example of a system including PV-T collectors and ground heat exchanger coupled with a water-to-water heat pump (source: ISFH and Fraunhofer ISE). 


\section{Subtasks}

The work in this T44A38 is divided into four Subtasks:

- Subtask A: Overview of solutions (existing, new) and generic systems, led by Sebastian Herkel from Fraunhofer ISE of Stuttgart, Germany;

- Subtask B: Performance assessment, led by Ivan Malenkovic from the Austrian Institute of Technology (AIT);

- Subtask C: Modelling and simulation, led by Michel Haller from the SPF in Rapperswil, Switzerland;

- Subtask D: Dissemination and market support, led by Wolfram Sparber form the EURAC Research centre in Bolzano, Italy.

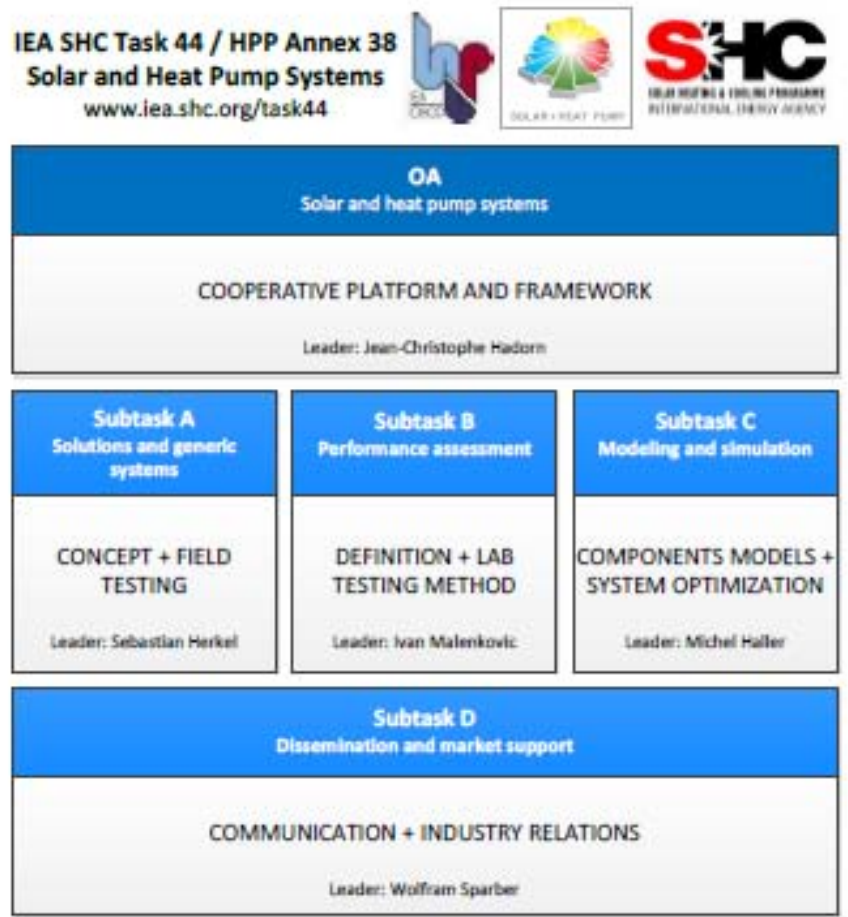




\section{Classification of Solar and Heat Pump systems}

An overview of the S+HP systems available on the European market have been carried out Within the activities of Subtask A. This has permitted to gather information regarding the major characteristics of these systems, with the aim of deriving a uniform classification.

From this investigation, several classification criteria became evident and among these have been selected:

- building load covered;

- heat pump's source;

- system layout.

The commercial S+HP systems identified on the EU market are 89. These are adopted for covering one or more building loads as depicted in Figure 2. The vast majority of S+HP systems covers Domestic Hot Water (DHW) and Space Heating (SH) loads (69 systems) of residential buildings, while 13 systems is devoted exclusively to $\mathrm{DHW}$ preparation. A number of systems (7) fulfils DHW, SH and Space Cooling (SC) loads.

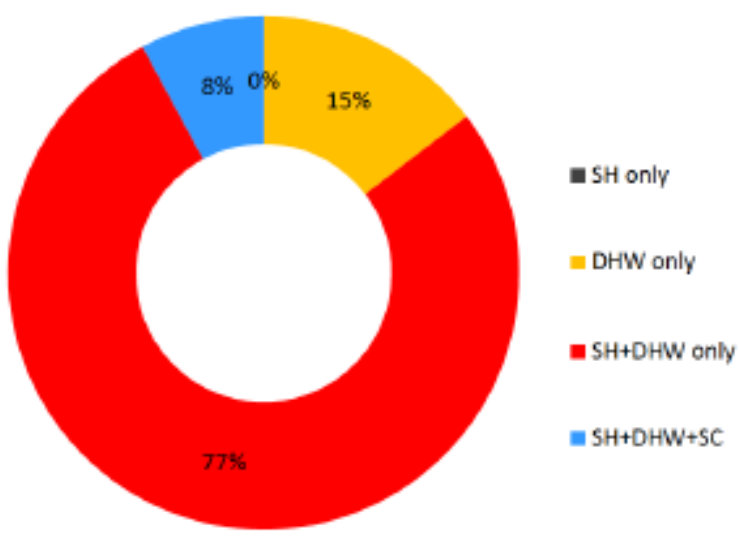

Figure 2: S+HP system dassification accordingly to the covered building load.

The heat sources of the heat pump can be the ambient air, solar energy, ground, well water or waster heat. These can be exploited singularly, simultaneously or alternatively, in accordance to the energy concept adopted by the manufacturer.

Looking at the mutual position of solar-thermal field and heat pump with respect to the building load (DHW or heating), S+HP systems can be further classified in pure parallel, 


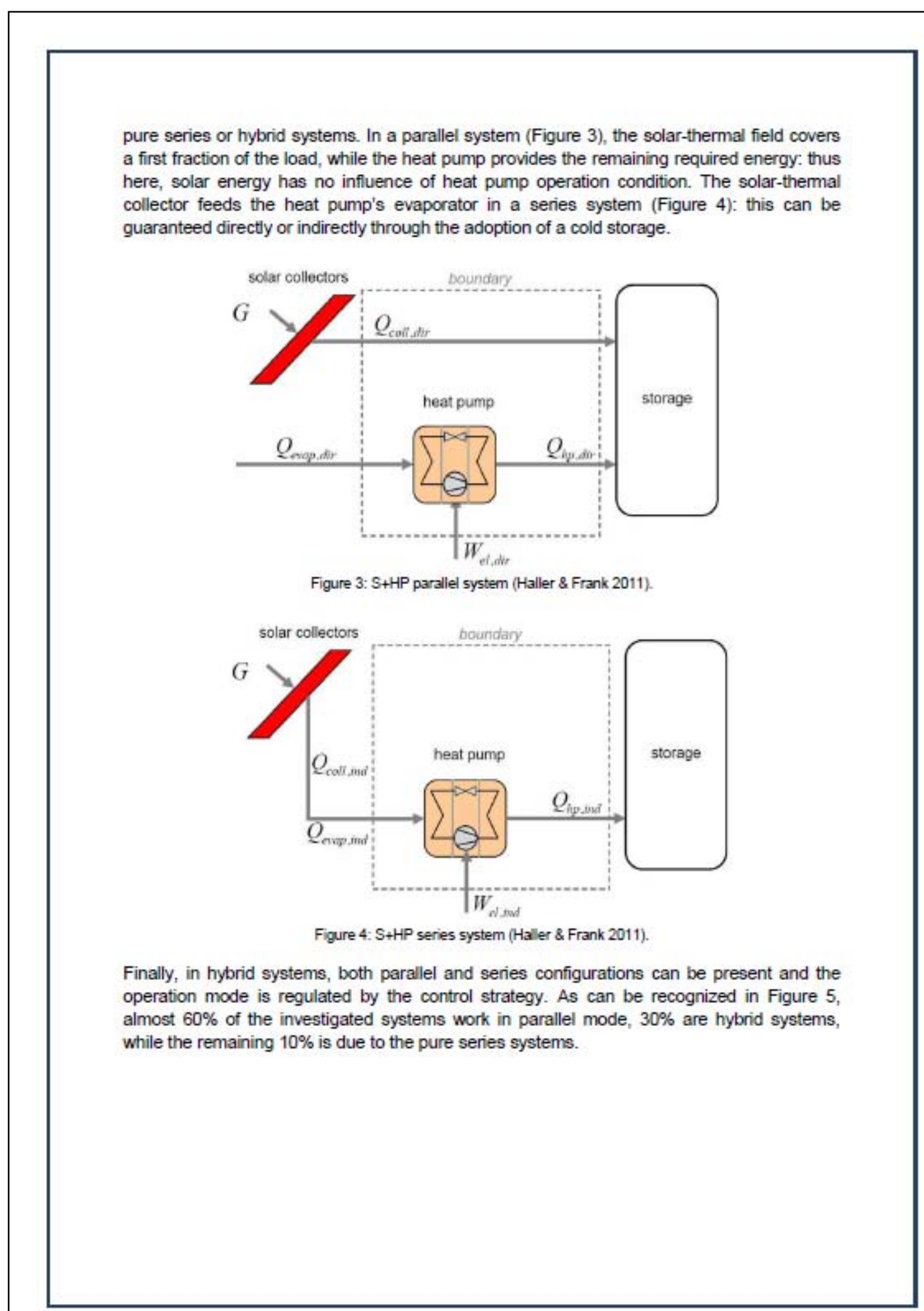




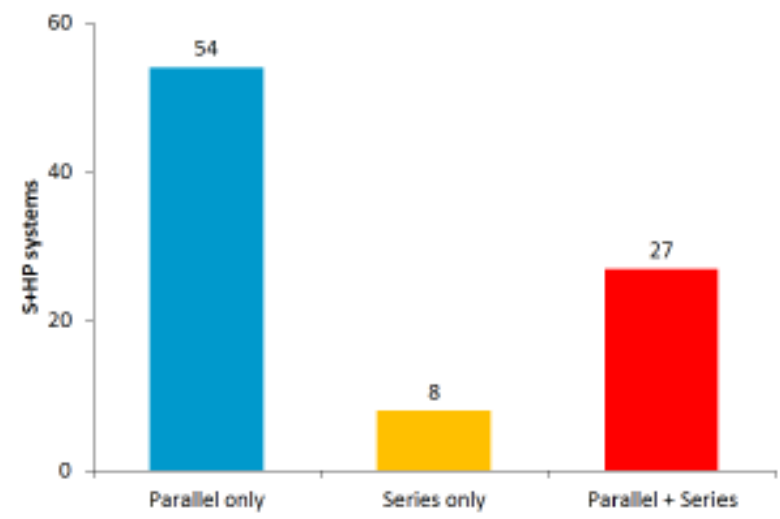

Figure $5: \mathrm{S}+\mathrm{HP}$ system classified accordingly to plant layout.

Grouping together the previous two criteria, the graph of Figure 6 can be derived. In the parallel systems, heat pump operates always as a monovalent system, adopting one single source among ambient air, ground, well water or waste heat. In pure serial systems, solar energy is most of the time used as a unique source (monovalent system), while in very limited cases ambient air or ground are used altematively. In hybrid parallel/series systems a great variety of plant layouts have been recognized. Here the combination of ground and solar energy showed to be the widest adoption.

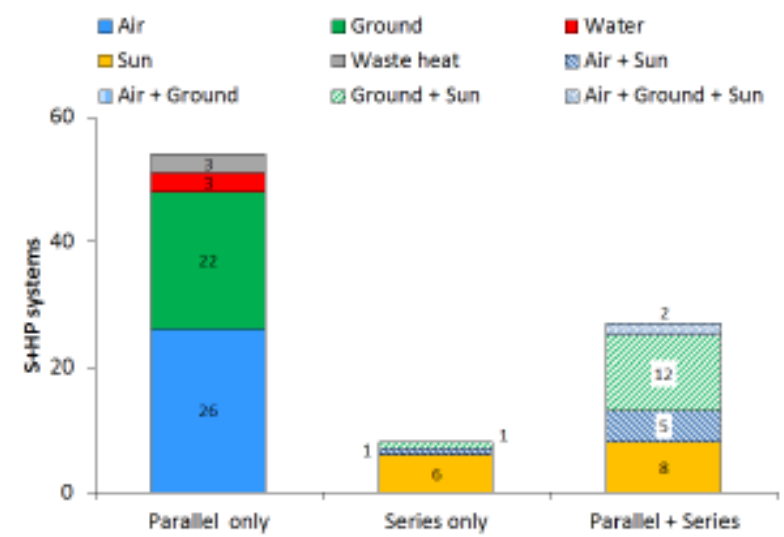

Figure $6: \mathrm{S}+\mathrm{HP}$ systems classified accordingly to the plant layout and heat pump source. 


\section{Energy flow chart}

In order to effectively describe S+HP systems, an energy flow chart has been created (Figure 7). This diagram has been developed accordingly to a source-sink approach, in which any component can virtually supply any other (source) with thermal or electric energy, or behaves as a sink of energy from any other. The clear benefit of this approach is the degree of freedom left to the description of the connections. All system components, as well mutual connections, are shown against a white background and the following convention have been established:

- in grey traded energy input/output to/from the system are accounted for:

- electricity,

- any other energy carrier fossil or renewable: gas, oil, wood, district heating circuit:

- in dark green free available renewable energy sources (RES) are reported:

- sun;

- ground;

- air;

- water,

- waste heat;

- in light green the heat exchangers between the RES and the systems are shown:

- solar collectors;

- ground probes;

- air/water, air/vapour heat exchangers;

- in dark blue the storages are set:

- cold storage, as heat source for the heat pump:

- hot storage, the one that could fulfil building loads (e.g. DHW storage, combi storage) and can be charged by solar energy or any heat generator system;

- in orange compression heat pumps and eventually the auxiliary heating system (e.g. heating rod);

in dark red the building loads.

Heat and electricity fluxes are represented with arrows among elements (from the source to the sink) accordingly to the source-sink approach. Electricity fluxes are represented in grey, themal energy is displayed in dark red. All arrows are also identified correspondingly to the source-sink approach.

Since electricity fluxes to pumps and fans would pack the diagram in case of complex systems, those components are shown as blue dots to be displaced on the diagram onto the respective energy fluxes: themselves represent the respective electricity consumption. 
A second clear advantage of this approach is that boundaries of the system and subsystems can be represented on the diagram and input/output energy fluxes can be detected, justifying the performance figures calculation and the meters needed for the acquisition of the needed data. In Figure 7, one exemplary boundary around the entire system have been sketched. Entering and leaving fluxes are clearly different and so are the meters to be used to describe the system and the performance figures computed.

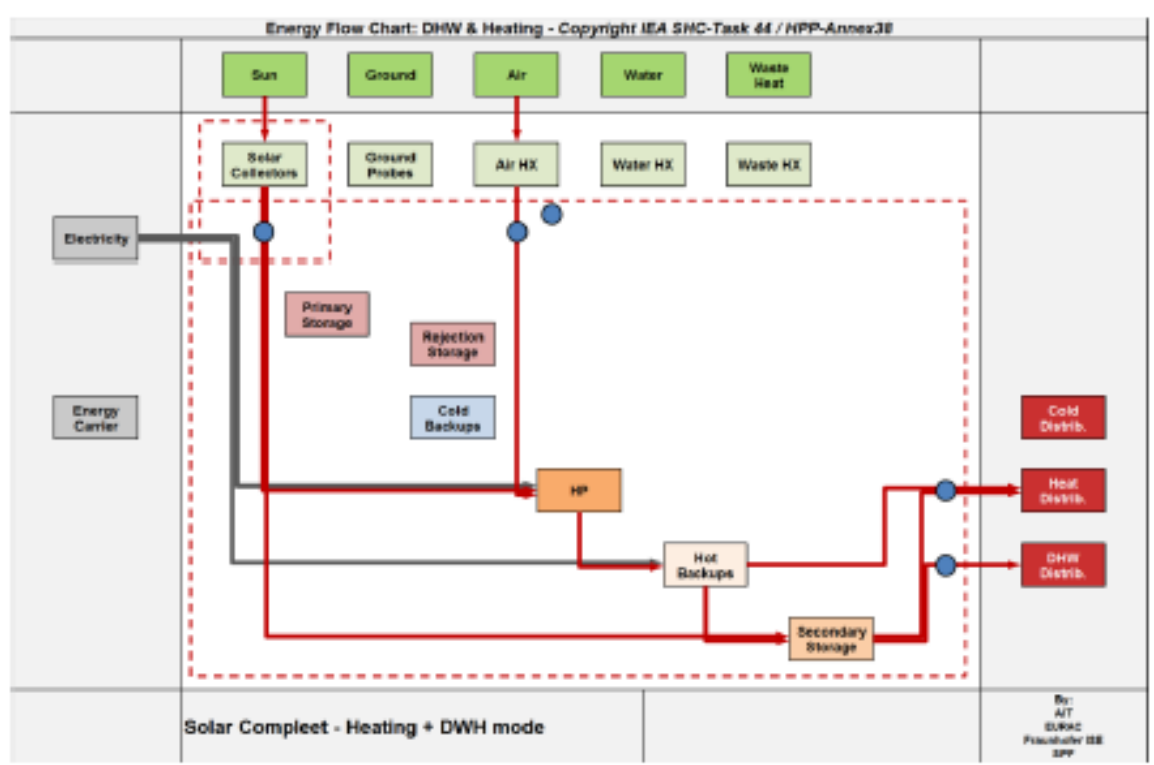

Figure 7: energy flow chart of S+HP system. 


\section{Source-sink generic table}

To easily manage the great variety of the connections, an Excel-based table has been elaborated where the first column shows all possible elements of the system, treated as sources, and the first row reports the same elements regarded as sinks (see Figure 8 ).

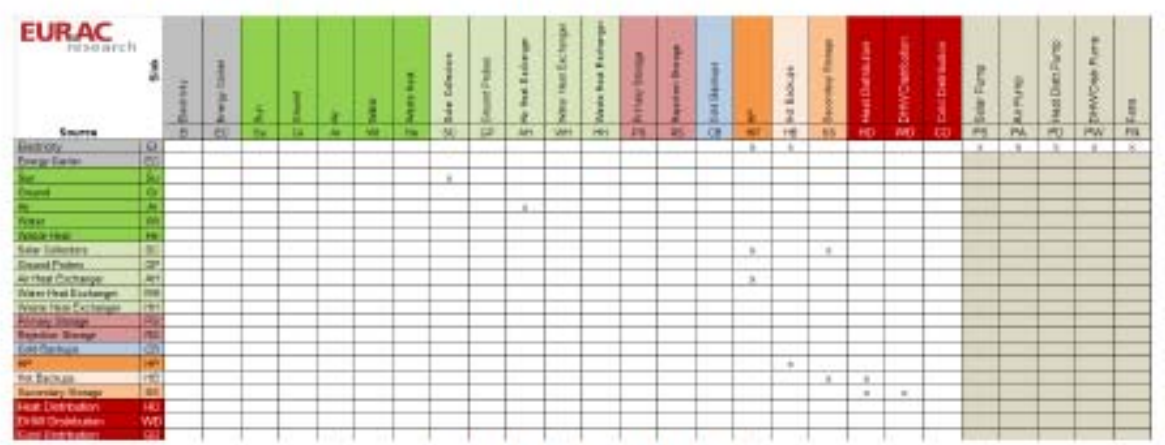

Figure 8: Source-sink table.

The elements are grouped together with different colours, accordingly to the nomenclature given above. Any element is fully identified by an two-letter code: first two letters of the name (Sun $=\mathrm{Su}$ ) or first letter of a composite name (Solar Collector $=$ SC) (see Figure 9). In this way any component is marked with an intuitive abbreviation: this will be then used to identify also all energy fluxes through the system. In particular the flux is named as: "source". "sink".

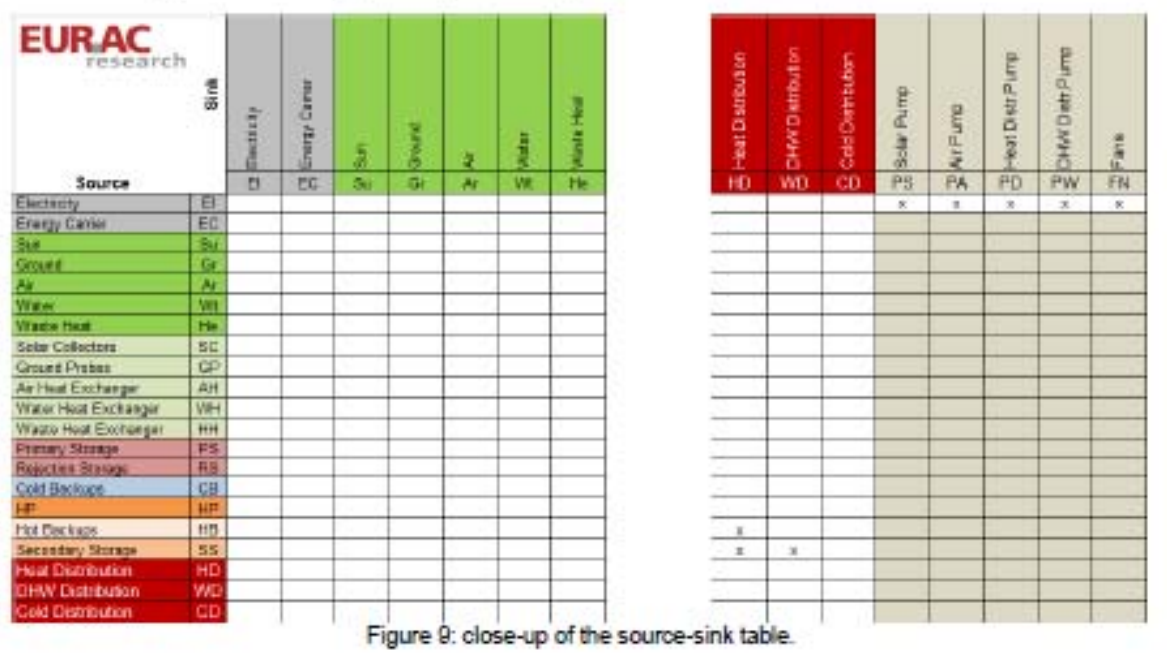




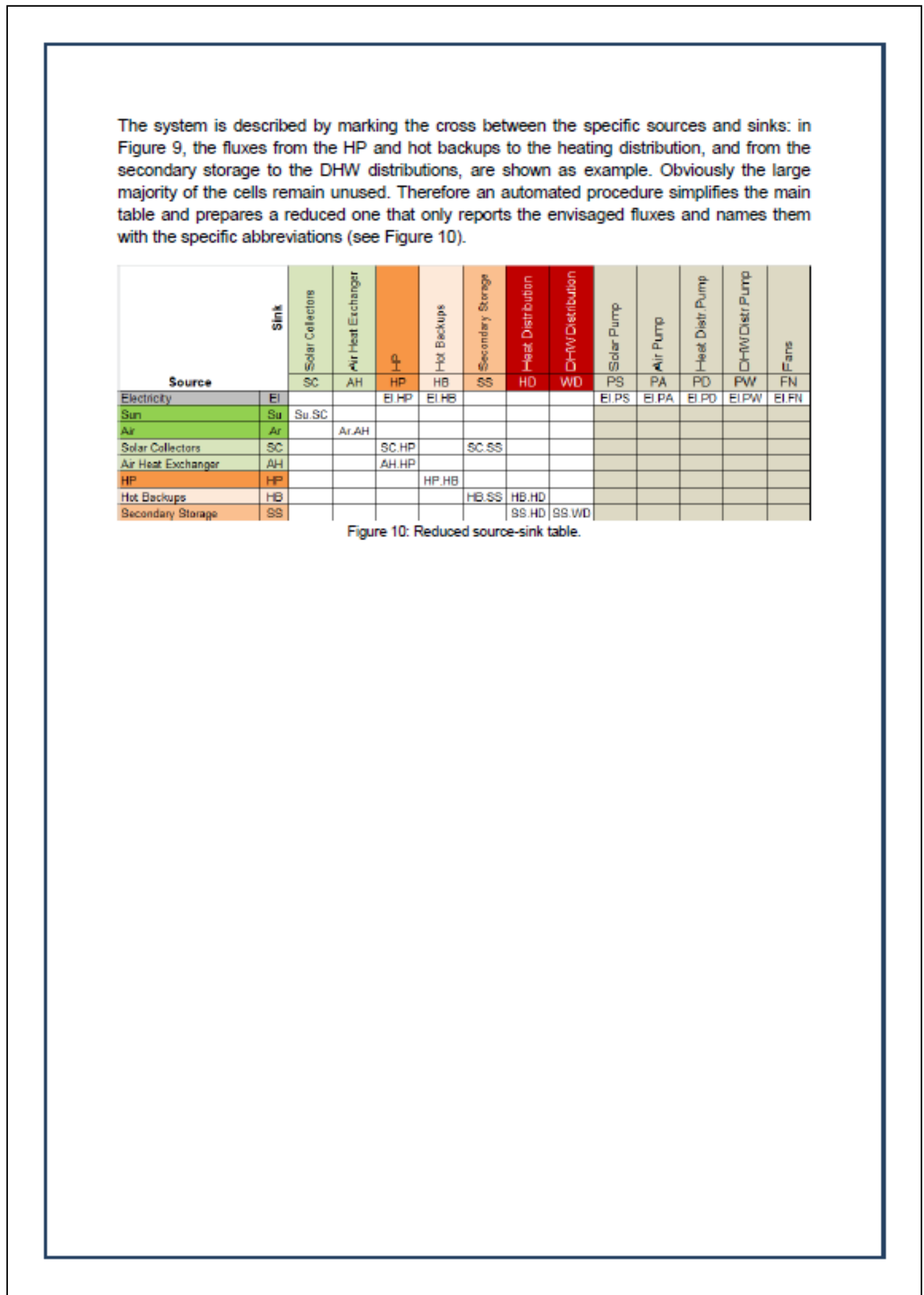




\section{Performance figures definition}

On the basis of the defined reference system, a set of system boundaries was proposed for the definition of different component and system performance figures. The proposed boundaries were chosen not only to suit SHP systems, but to be applicable to a broad variety of heating systems and technologies in order to enable a transparent comparison between them.

When defining the boundaries, the following goals were pursued:

1. Overall system performance including energy distribution system. Possibility of an energetic, economic and ecological evaluation of the whole system - overall energy balance, purchased energy, free energy, emissions etc. The information is interesting for the user, the policy, statistical evaluation etc.

2. Possibility of an economic and ecological evaluation of the energy producing system, without the energy distribution system, which is different for every application. Interesting for product quality assurance, labelling, manufacturers, planers, installers, comparison between different systems and technologies regarding efficiency, primary energy, emissions etc.

3. Performance of the system without the influence of the storage losses - decoupling of the energy producing part and energy storage part. Interesting e.g. for control analysis (production-demand), dimensioning etc. Mainly interesting for system analysis (manufacturers, R\&D etc.).

4. Performance of each "energy transformation unit" (e.g. heat pump), including all parts needed for its proper functioning (e.g. heat sources). Performance of each unit under given circumstances gives information about the efficiency of every subsystem and possible improvements. Interesting for component and subcomponent manufacturers, planners and installers, system analysis etc.

5. Performance of each energy transformation unit for itself, without influence of the "auxiliary" energy (energy sources etc.). This closely corresponds to the energy balance used currently in most quality assurance schemes both for solar thermal collectors and heat pumps (e.g. Solar Keymark, EHPA Quality Label). By comparison with other performance figures, an analysis of the system regarding peripheral energy consumption can be made. Interesting for manufacturers, planers etc.

Starting from these five goals for a comprehensive analysis of an energy producing system, system boundaries for SHP systems can be defined, Figure 11. At this stage, the boundaries have been defined for heating operation and domestic hot water (DHW) production only. The cooling mode will also be considered. 


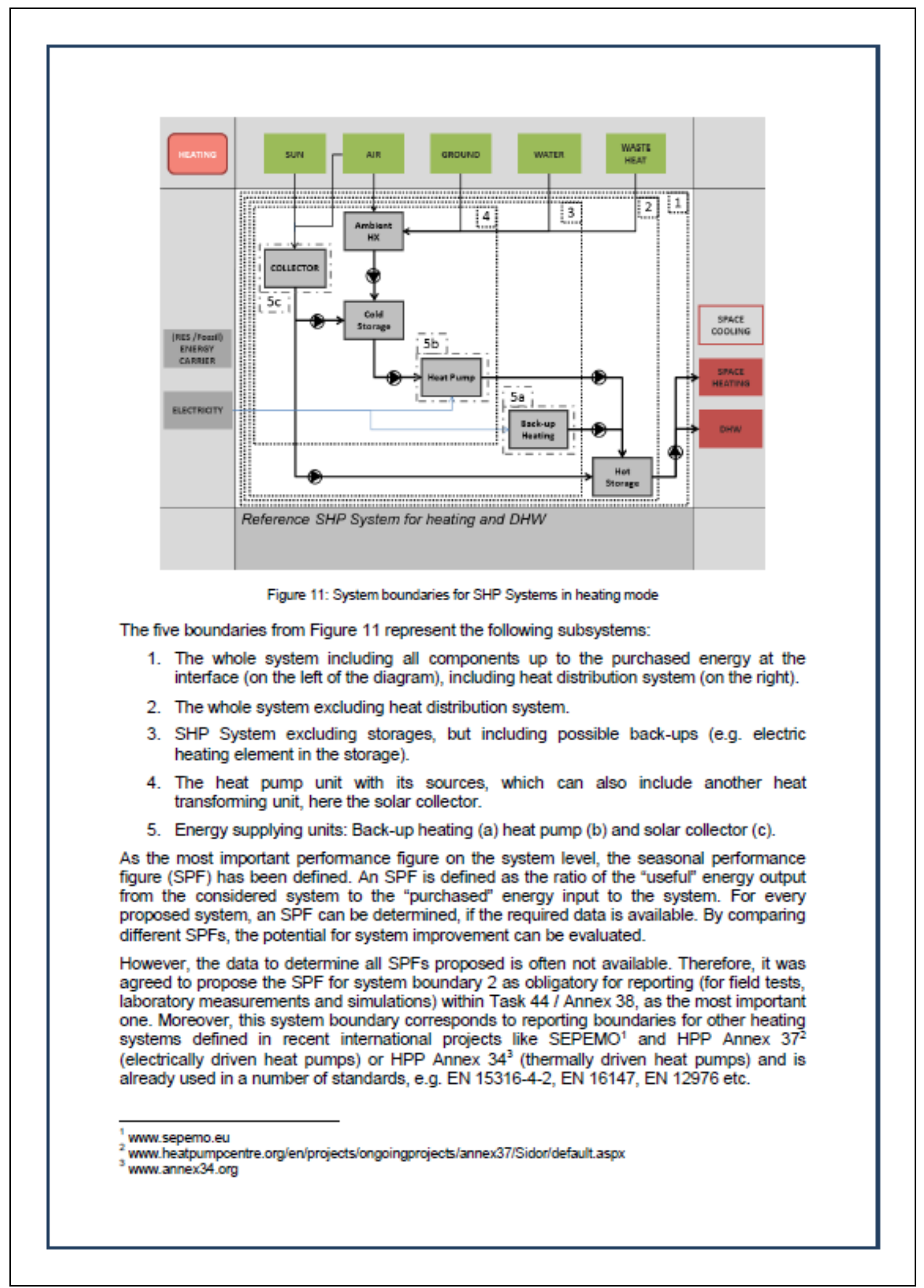




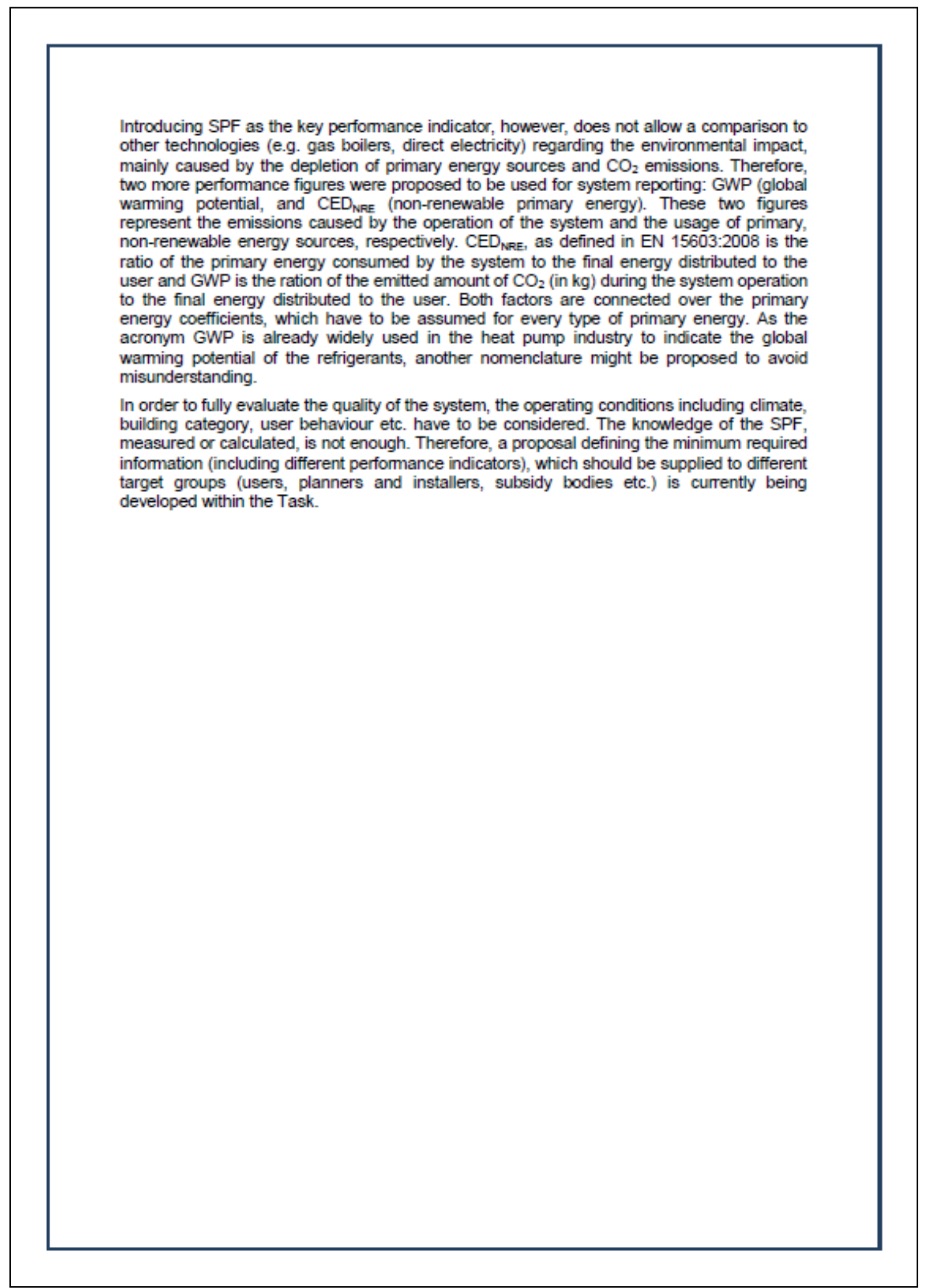


Task 44 / Annex 38 - Participants

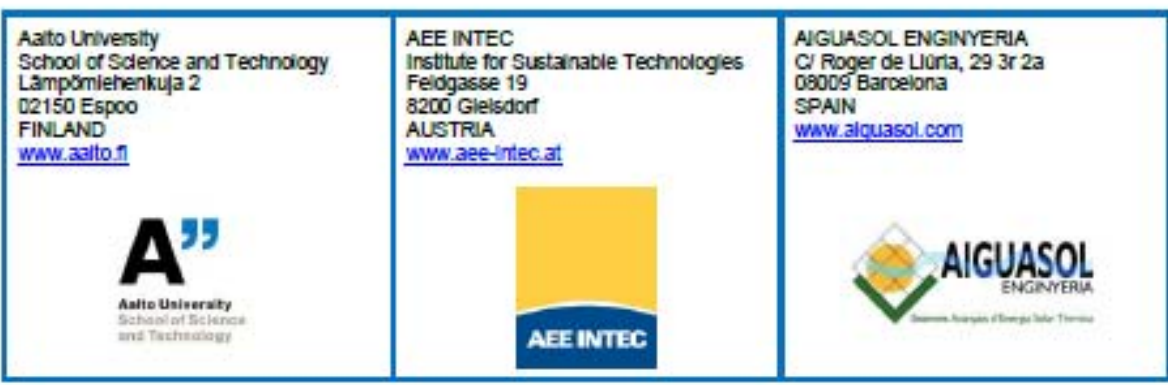

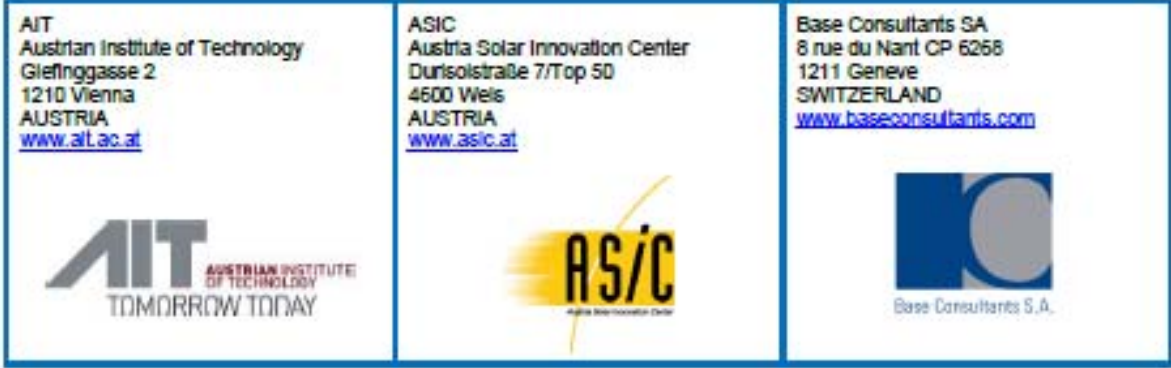

\begin{tabular}{|c|c|c|}
\hline 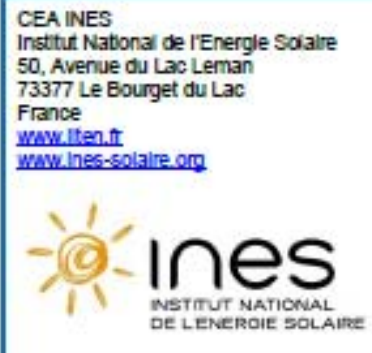 & $\begin{array}{l}\text { CENERGIA } \\
\text { Heriev Hovedgade } 196 \\
2730 \text { Herlev } \\
\text { DENMARK } \\
\text { wwwicenerglads }\end{array}$ & $\begin{array}{l}\text { Consolar } \\
\text { Solare Energlesysteme GmbH } \\
\text { Gewervestrasse } 7 \\
79539 \text { Lơrach } \\
\text { GERMANY } \\
\text { WwW.consolar.de }\end{array}$ \\
\hline
\end{tabular}

\begin{tabular}{|c|c|c|}
\hline $\begin{array}{l}\text { DANISH } \\
\text { TECHNOLOGICAL } \\
\text { INSTITUTE }\end{array}$ & $\begin{array}{l}\text { DTU } \\
\text { Technical University of Dermark } \\
\text { Anker Engelundsvej } 1 \\
2800 \text { Kgs. Lyngby } \\
\text { DENMARK } \\
\text { wWw dtudk }\end{array}$ & 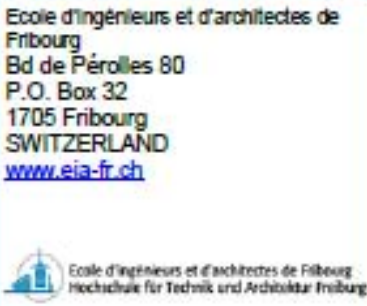 \\
\hline
\end{tabular}




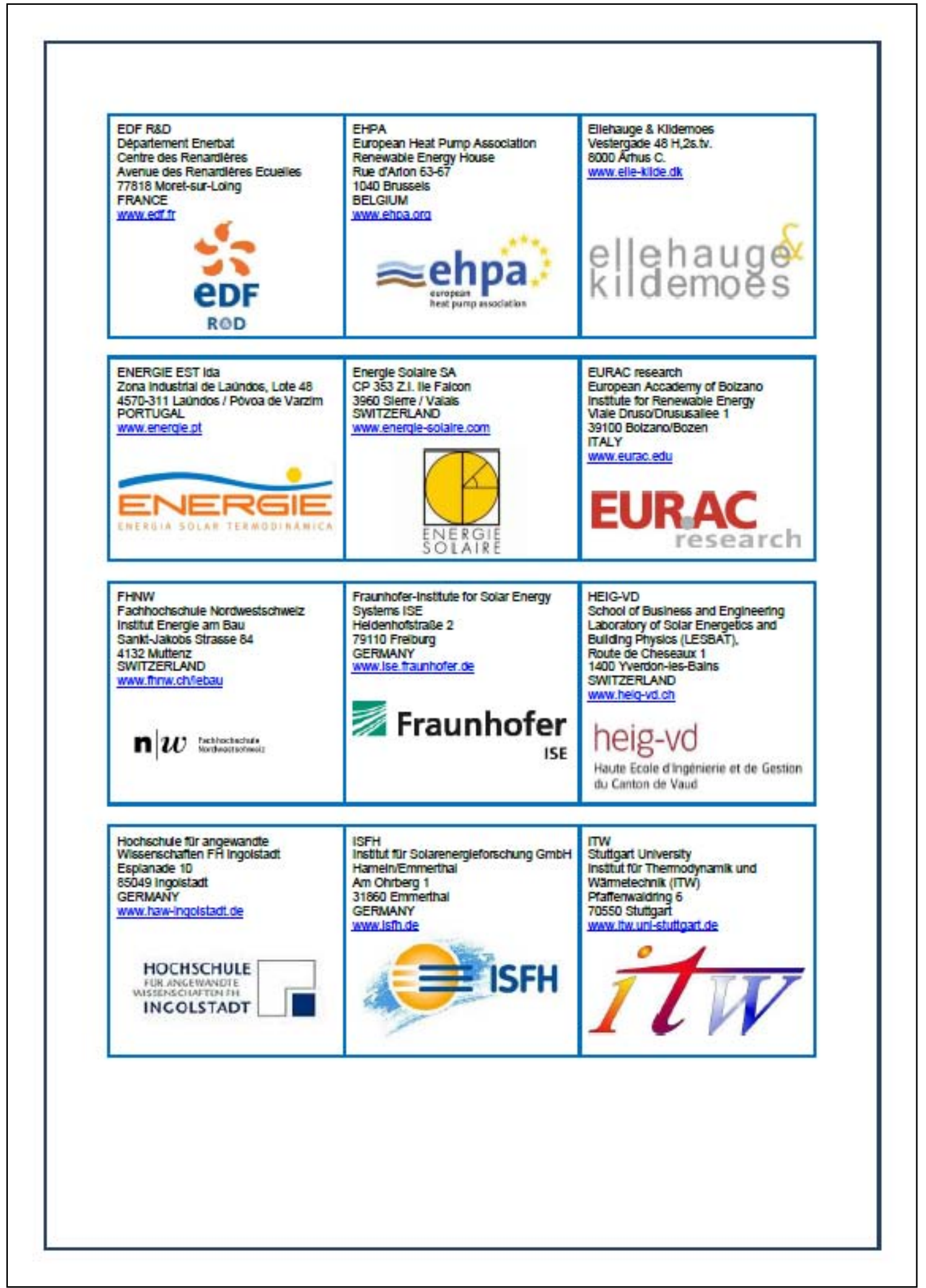




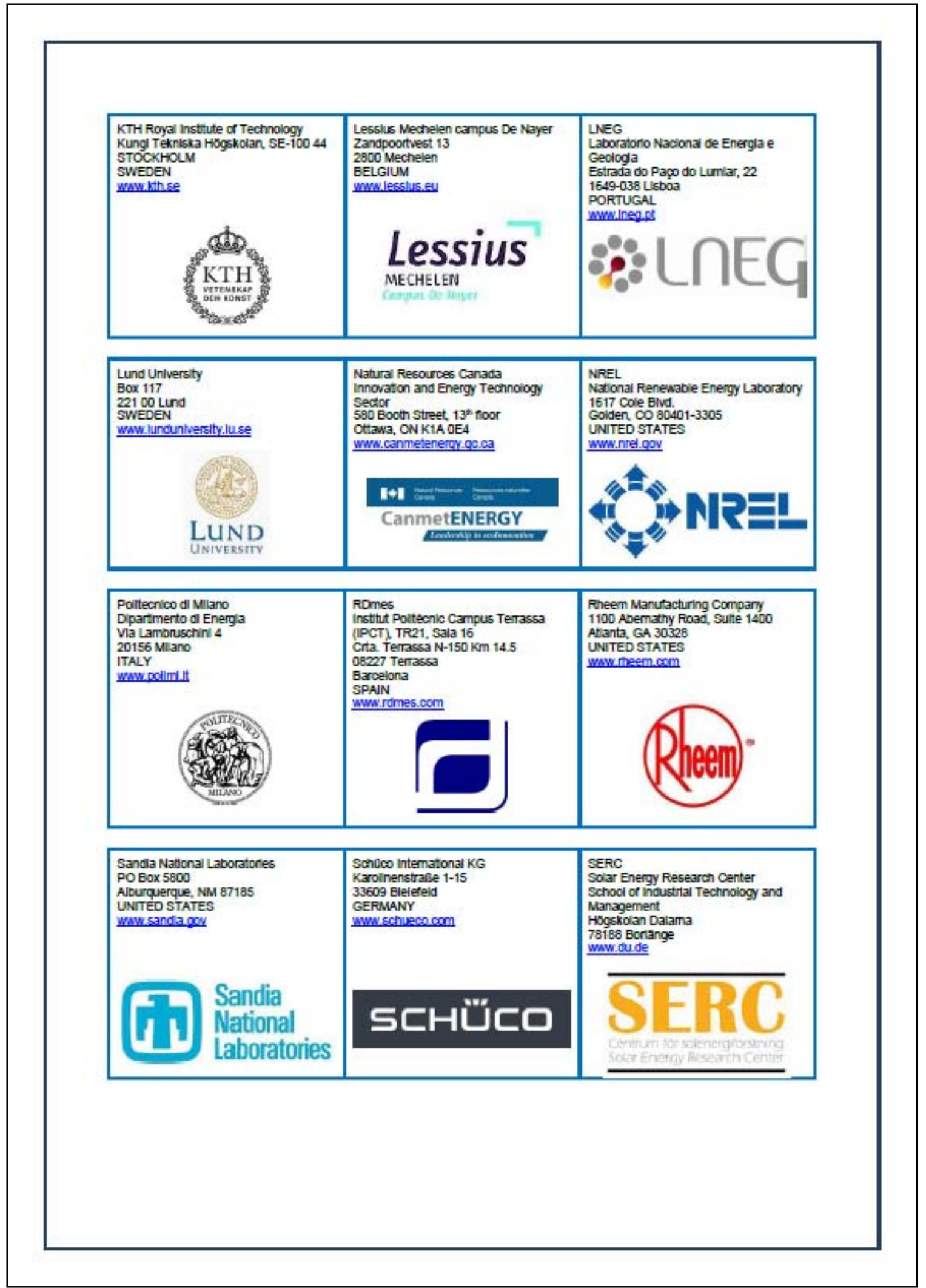




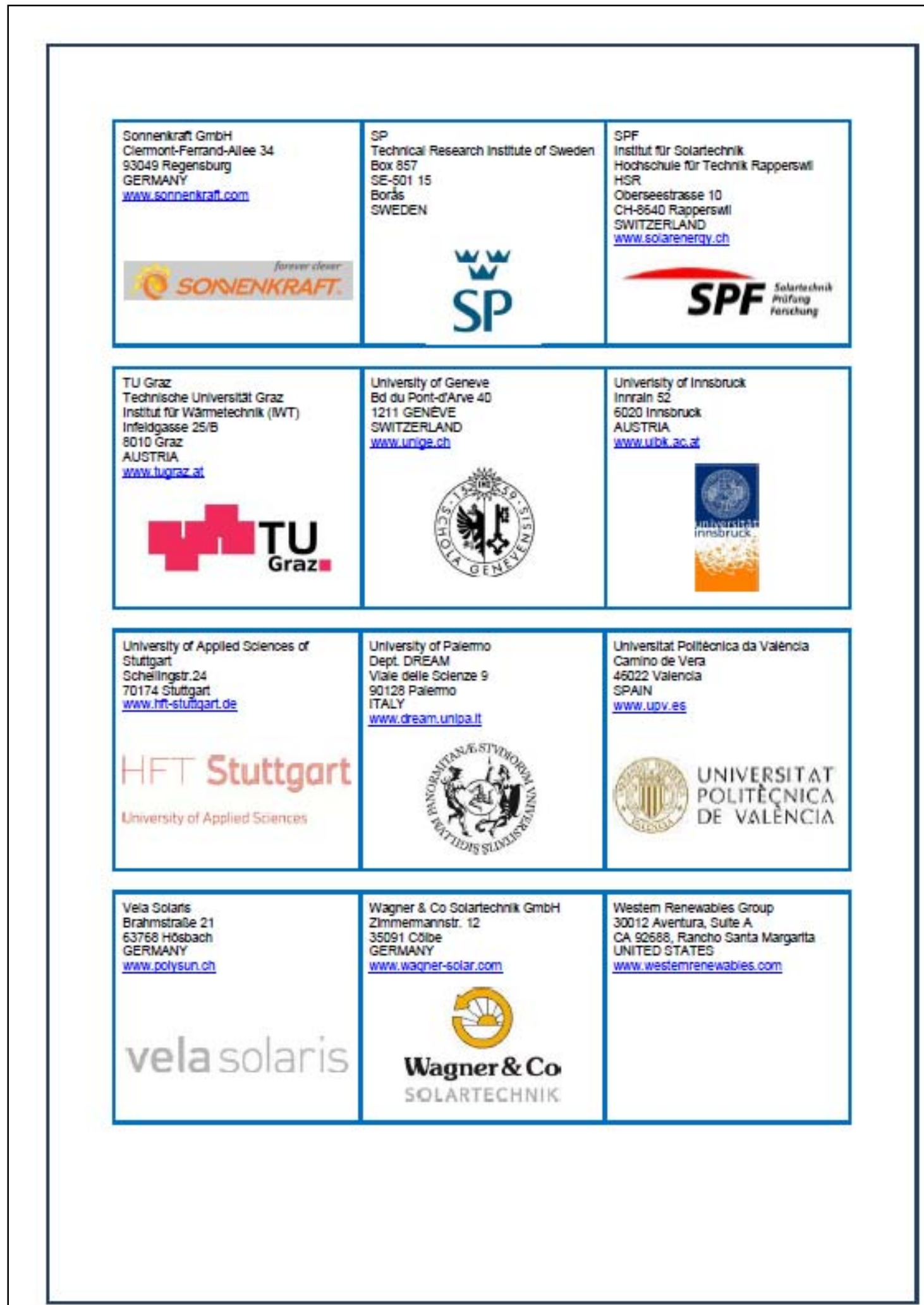




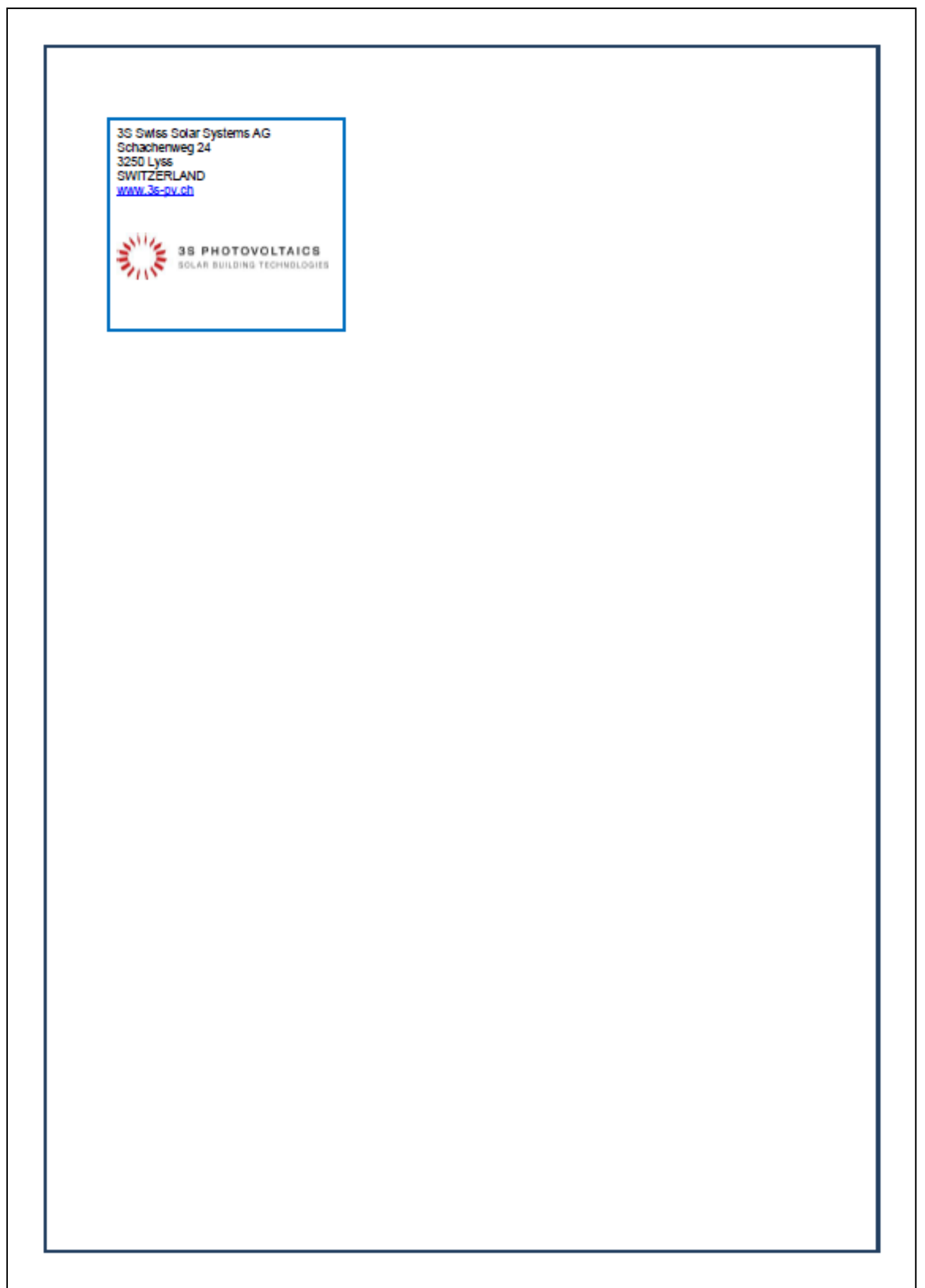




\section{Third newsletter}

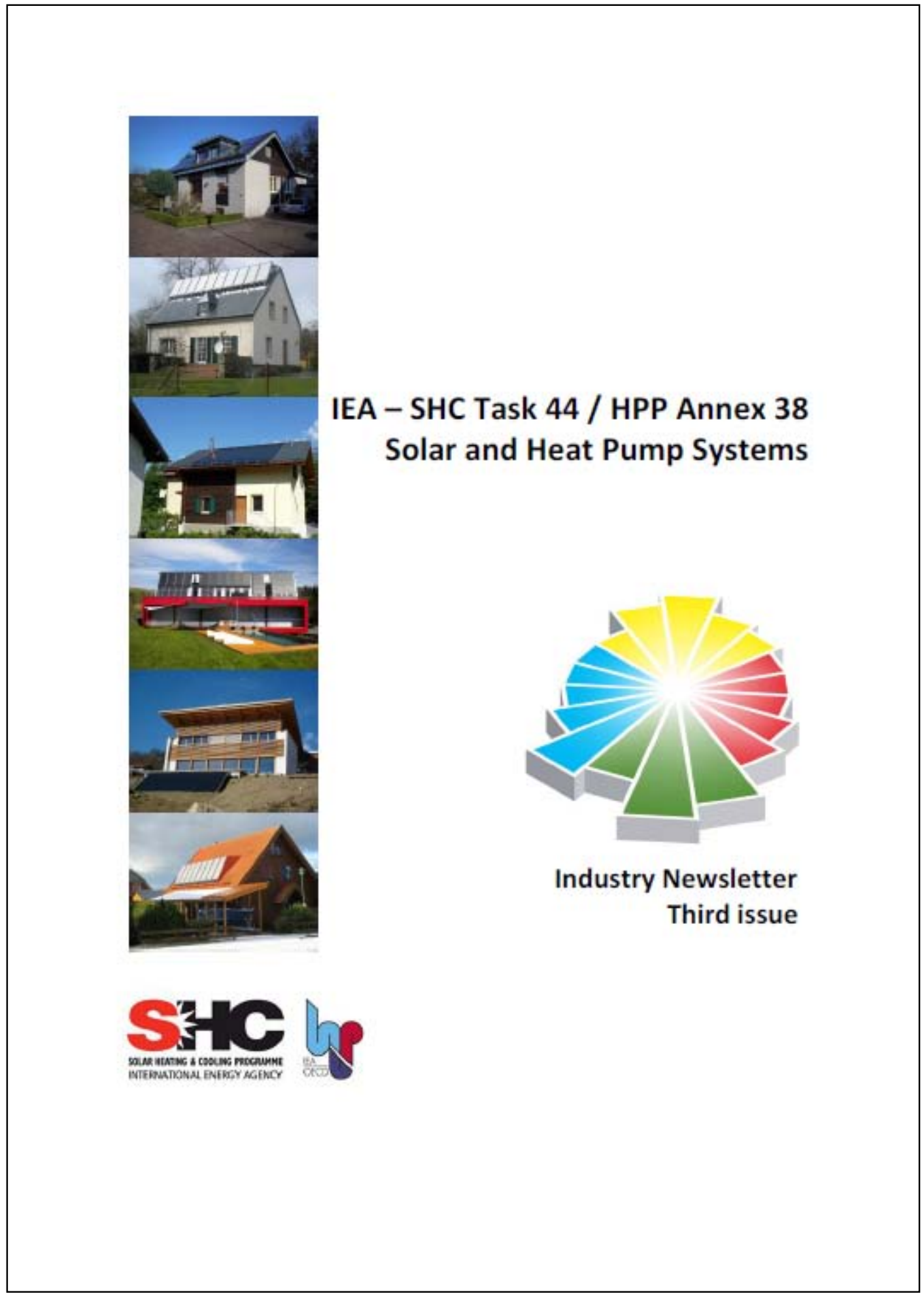




\title{
Industry newsletter
}

Third issue, 2-2013

\section{IEA - SHC Task 44 / HPP Annex 38}

\section{Solar and Heat Pump Systems}

\author{
Elaborated by: \\ M. D'Antoni, R. Fedrizzi, W. Sparber \\ EURAC Research \\ With contributions by: \\ Michel Haller, SPF Solartechnik (Switzerland) \\ Martin Vukits, AEE Intec (Austria) \\ Erik Bertram, Institute for Solar Energy Research Hamein ISFH (Germany)
}

This newsletter presents three examples of commercially available Solar plus Heat Pumps systems monitored within IEA Task 44 / Annex 38. Here, domestic hot water and space heating demand of existing residential buildings are covered through the combination of a compression heat pump and solar thermal collectors. More detailed information are available in the referenced literature.

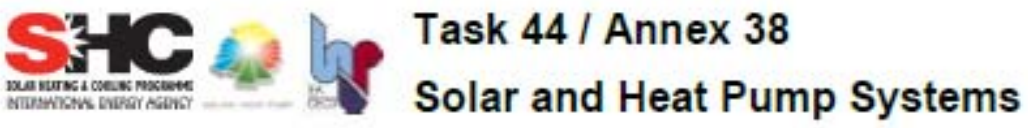




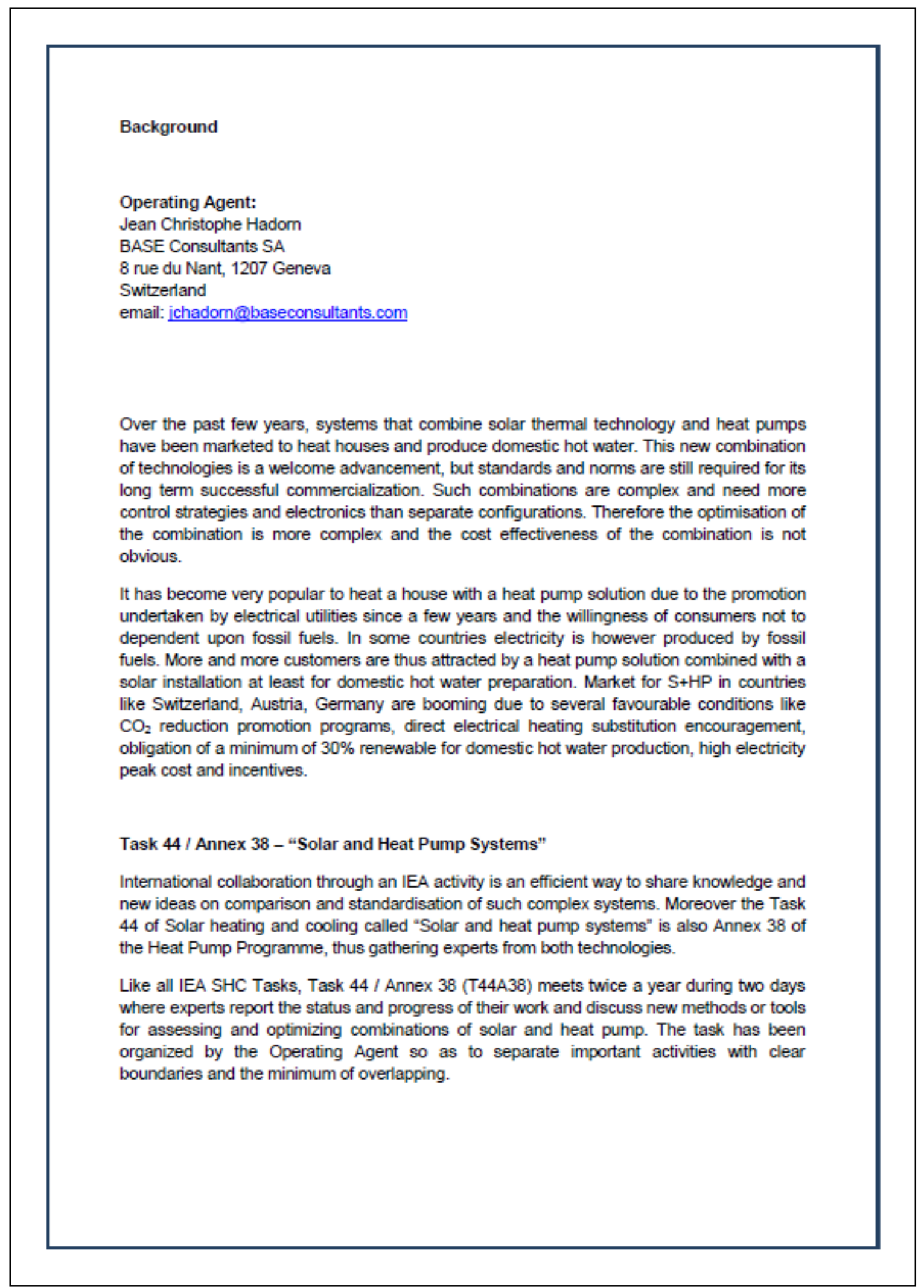




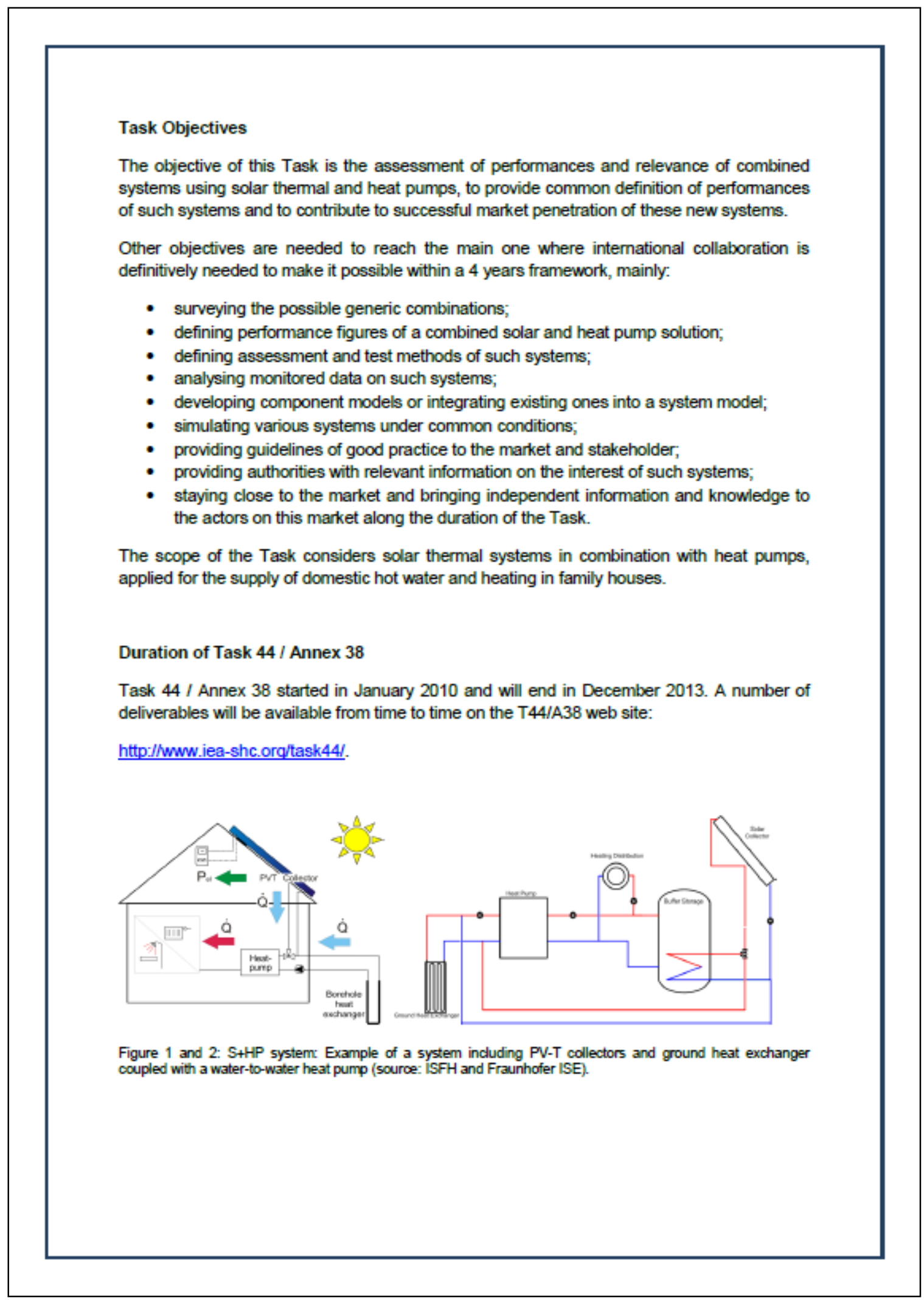




\section{Subtasks}

The work in this T44A38 is divided into four Subtasks:

- Subtask A: Overview of solutions (existing, new) and generic systems, led by Sebastian Herkel from Fraunhofer ISE of Stuttgart, Germany;

- Subtask B: Performance assessment, led by Ivan Malenkovic from the Austrian Institute of Technology (AIT);

- Subtask C: Modelling and simulation, led by Michel Haller from the SPF in Rapperswil, Switzerland;

- Subtask D: Dissemination and market support, led by Wolfram Sparber form the EURAC Research centre in Bolzano, Italy.

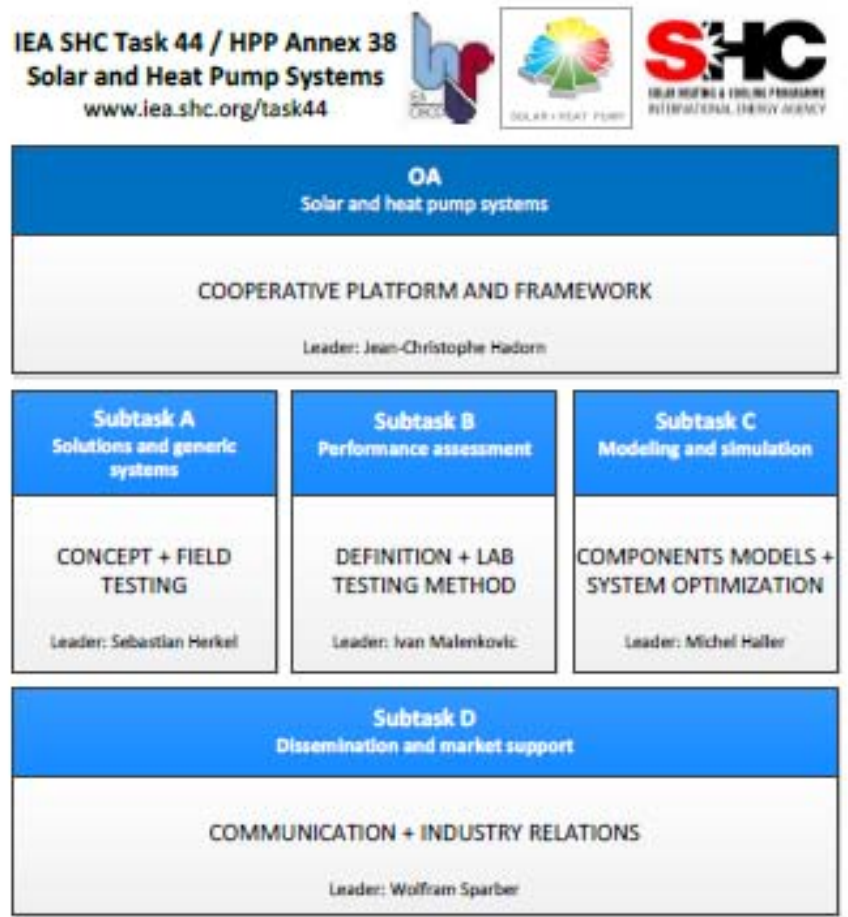




\section{Introduction}

The aim of the $3^{\text {rd }}$ issue of T44A38 newsletter is to focus on monitoring results of Solar and Heat Pump $(\mathrm{S}+\mathrm{HP})$ systems. Since a raising number of standardized kits and solutions combining compression heat pumps and solar thermal collector for covering Domestic Hot Water and Space Heating demand are always more available on the market, it is of major interest to understand the actual performance in real operating conditions.

Within the multitude of different solutions combining solar energy with heat pump systems, three examples are here presented. Typical European residential buildings equipped with a S+HP system have been monitored for a year at least. Monitoring data are presented accordingly to IEA SHC Task 44 / HPP Annex 38 approach in calculating system performance figures. This work does not aim to report on the most efficient S+HP systems; it has to be seen as review of some existing systems. 


\section{Calculation method}

In order to compare different layout scheme of Solar and Heat Pump systems within the IEA SHC Task 44 / Annex 38, a common definition on the performance calculation method has been done. As reported in [1], a series of indexes have been suggested as those which better quantify and represent the influence of solar energy exploitation on heat pump's seasonal performance. Each indicator refers to a system boundary, in order to put in light the behaviour of each system component. However, for sake of brevity, only three indicators have been here presented and in particular the:

- system boundary SHP+: this boundary contains all components of the system including the space heating and DHW distribution system in terms of pumping electrical energy consumption;

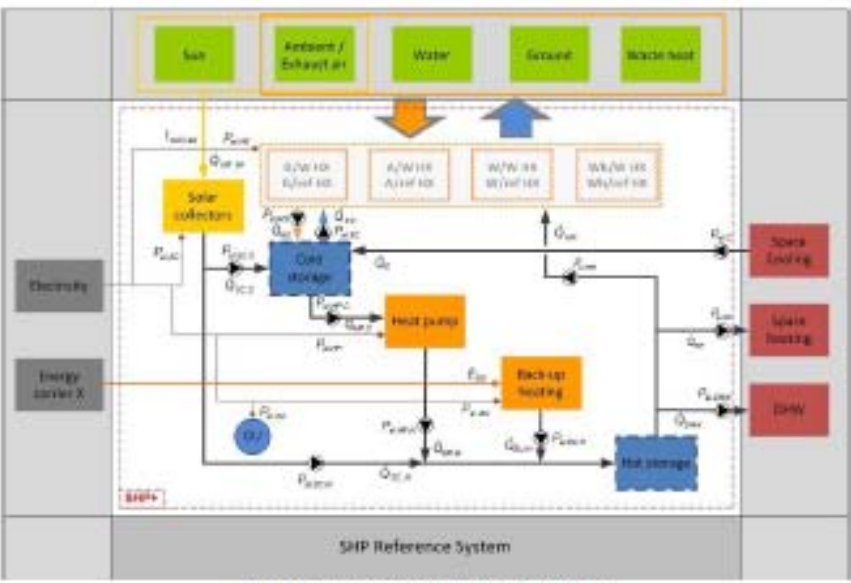

Figure 2 system boundary SHP+ [1] 


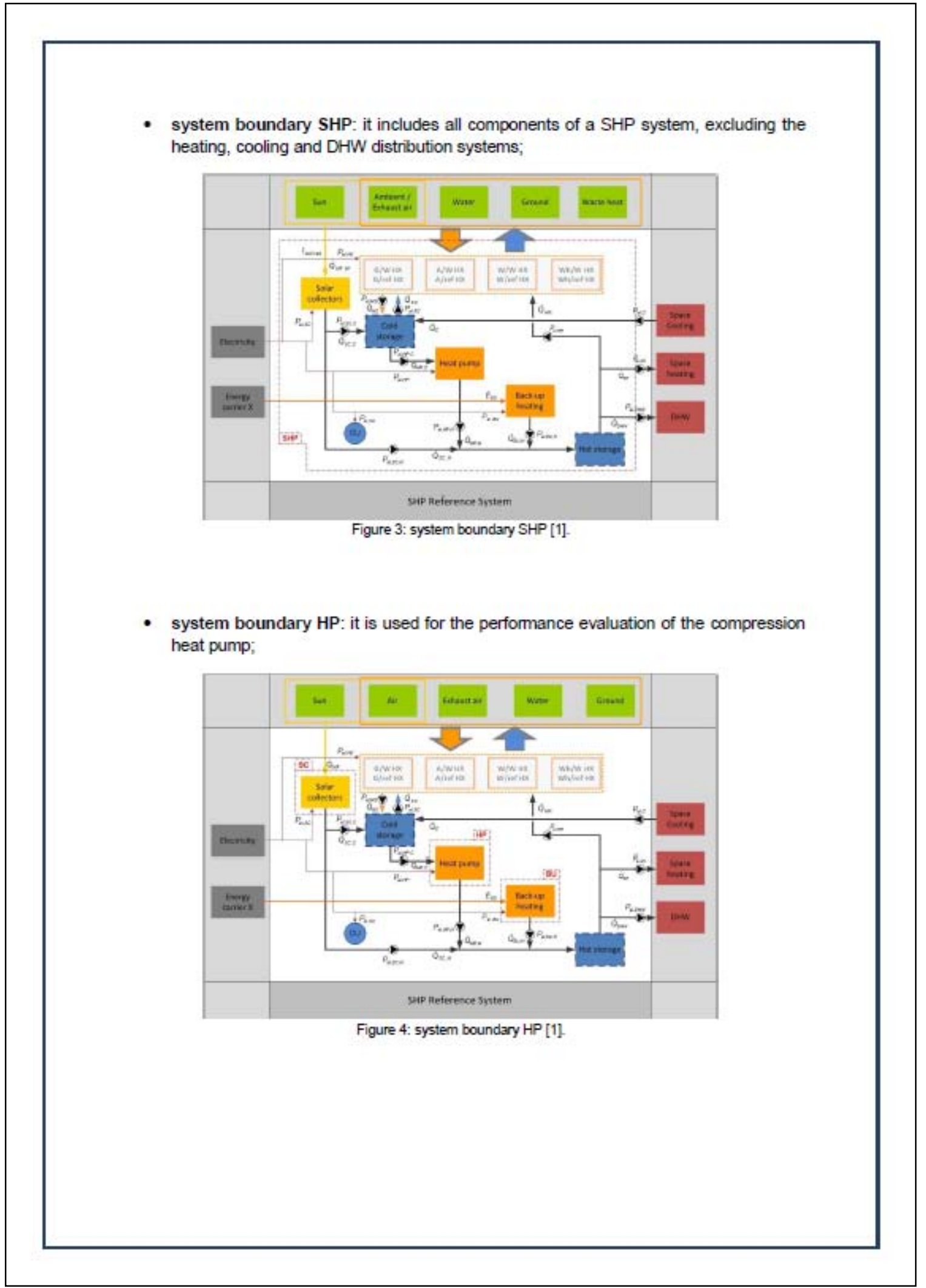




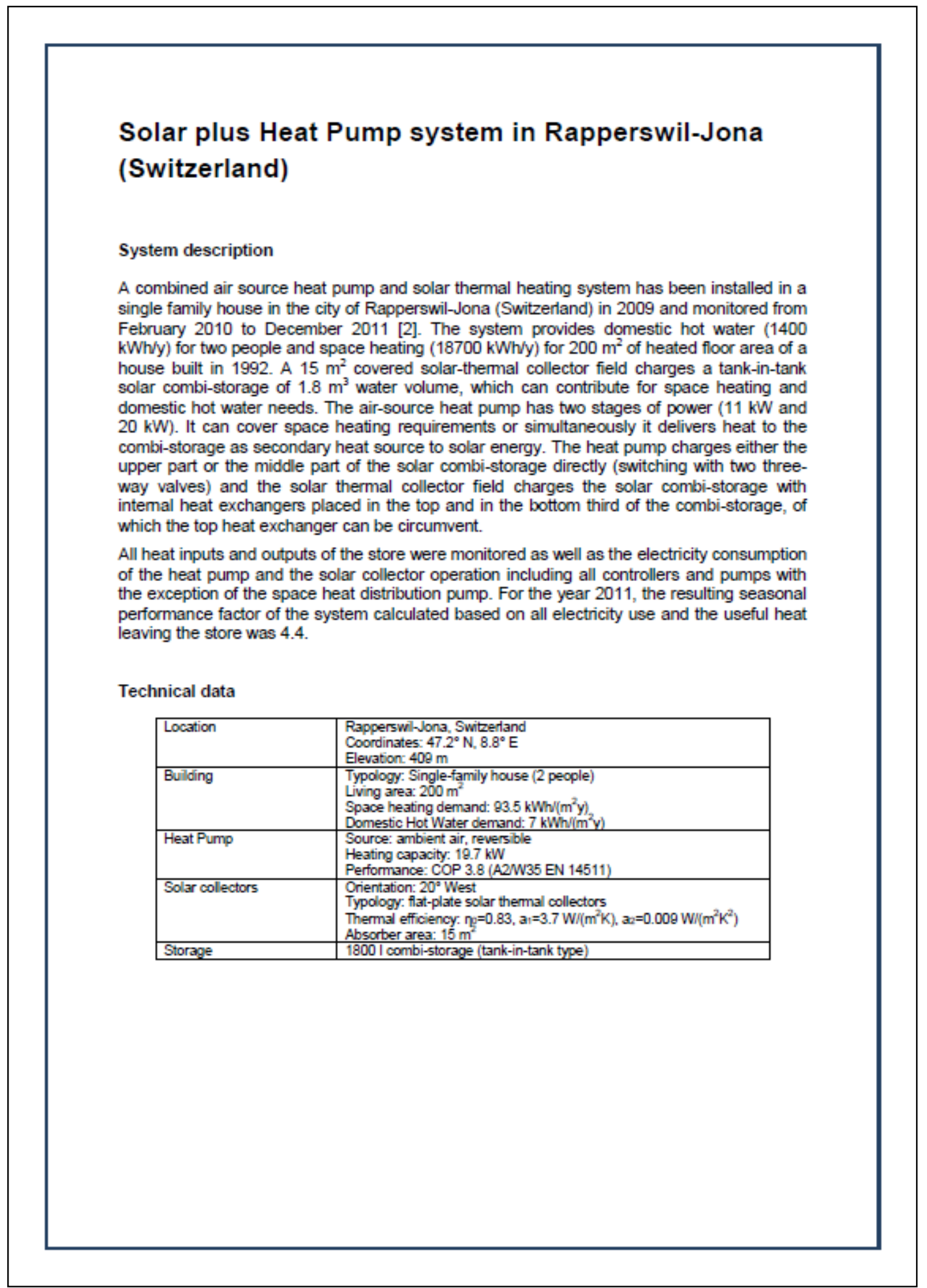




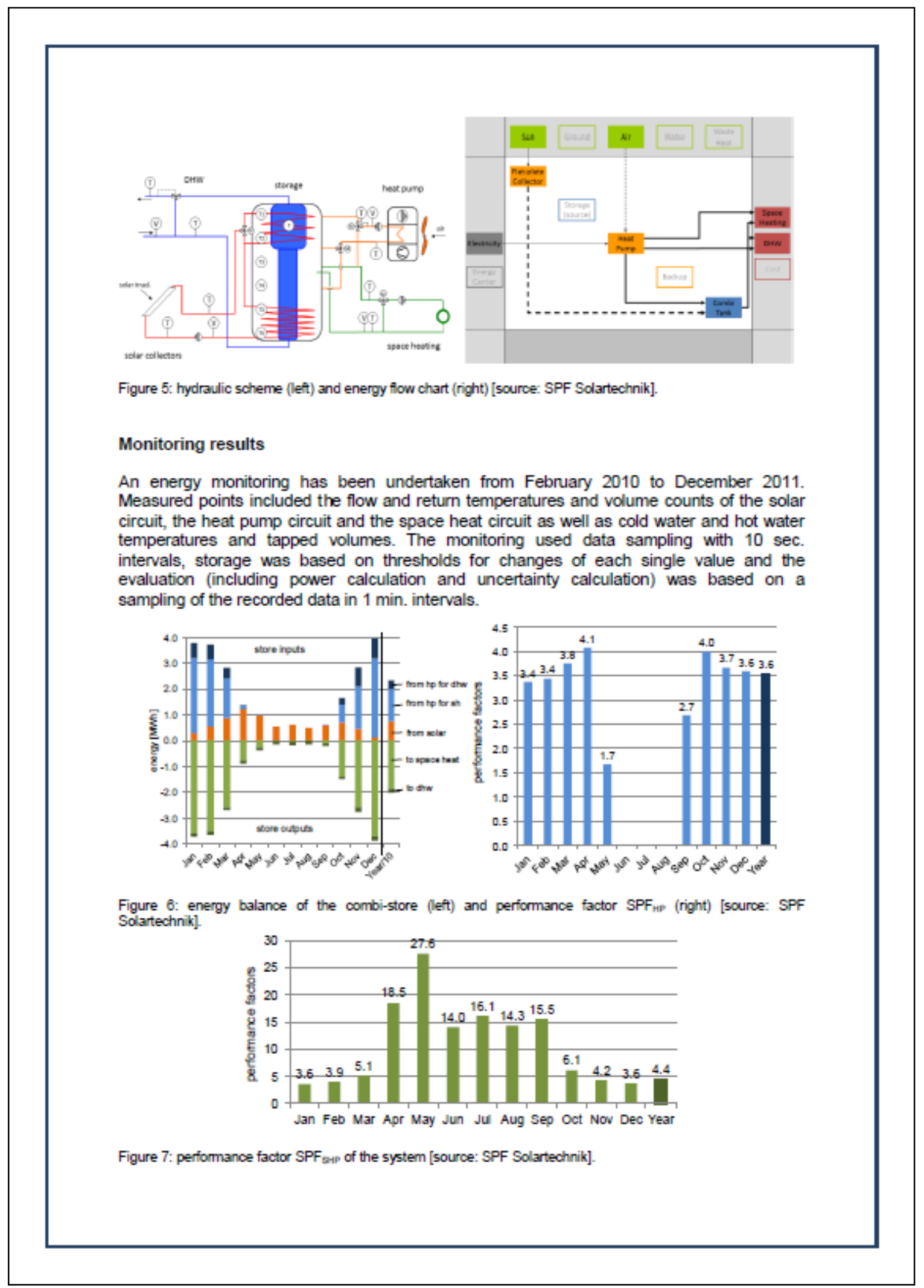




\section{Solar plus Heat Pump system in Trofaiach (Austria)}

\section{System description}

A combined air source heat pump and solar thermal heating system has been installed into a single family house with a small workshop (electrician) in Trofaiach (Austria) and monitored from October 2010 to February 2012 [3-4]. The system provides domestic hot water (2685.5 $\mathrm{kWh} / \mathrm{y})$ for 4 people and space heating $(28094.3 \mathrm{kWh} / \mathrm{y})$ for $300 \mathrm{~m}^{2}$ heated floor area. The $9.5 \mathrm{~kW}$ air source heat pump and the $15 \mathrm{~m}^{2}$ flat-plate collectors deliver heat to a combistorage of 1000 I water volume from where the needs for space heat and domestic hot water are served. The energy from the solar collectors can also support the heat pumps evaporator. All heat inputs and outputs of the storage were monitored as well as the electricity consumption of the heat pump and the rest of the system. For the year 2011, the resulting seasonal performance factor of the system calculated based on all electricity use and the useful heat leaving the storage was 2.59 .

\section{Technical data}

\begin{tabular}{|c|c|}
\hline Location & $\begin{array}{l}\text { Trofaiach, Austria } \\
\text { Coordinates: } 47.4^{\circ} \mathrm{N}, 15.0^{\circ} \mathrm{E} \\
\text { Elevation: } 685 \mathrm{~m}\end{array}$ \\
\hline Bullding & $\begin{array}{l}\text { Typology: Single-family house ( } 4 \text { people) } \\
\text { Living area: } 300 \mathrm{~m}^{2} \\
\text { Space heating demand: } 93.65 \mathrm{kWh} /\left(\mathrm{m}^{2} \mathrm{y}\right) \\
\text { Domestic Hot Water: } 8.95 \mathrm{kWh} /\left(\mathrm{m}^{2} \mathrm{y}\right)\end{array}$ \\
\hline Heat Pump & $\begin{array}{l}\text { Source: ambient air and water (solar energy) } \\
\text { Heating capacity: } 9.5 \mathrm{~kW} \\
\text { Performance: COP } 3.3 \text { (A2N35 EN 255) }\end{array}$ \\
\hline Solar colectors & $\begin{array}{l}\text { Orientation: } 35^{\circ} \text { West } \\
\text { Typology: flat-plate solar themal collectors } \\
\text { Thermal efficiency: } \eta_{p}=0.746, a_{1}=3.232 \mathrm{~W} /\left(\mathrm{m}^{2} \mathrm{~K}\right), \mathrm{a}_{2}=0.014 \mathrm{~W} /\left(\mathrm{m}^{2} \mathrm{~K}^{2}\right) \\
\text { Aperture area: } 15 \mathrm{~m}^{2}\end{array}$ \\
\hline Storage & 1000 combi-storage with 2 immersed heat exchangers \\
\hline
\end{tabular}

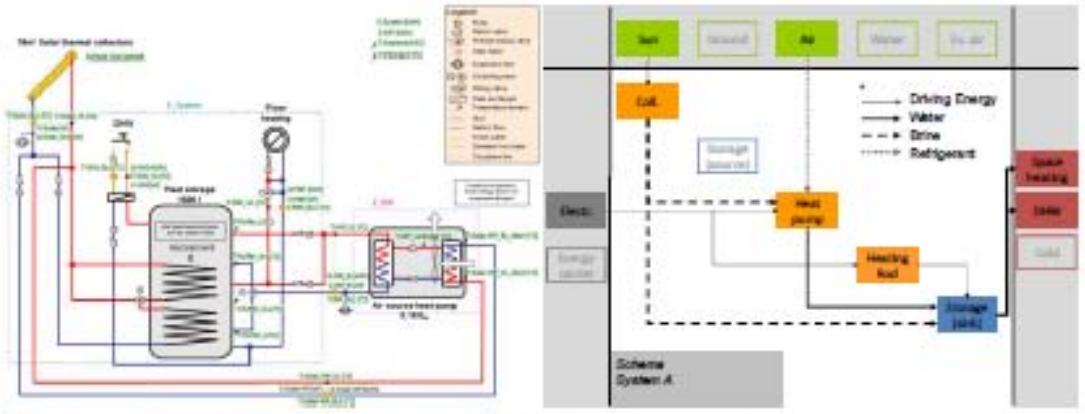

Figure 8: hydraulic scheme (left) and energy flow chart (right) [source: AEE Intec]. 


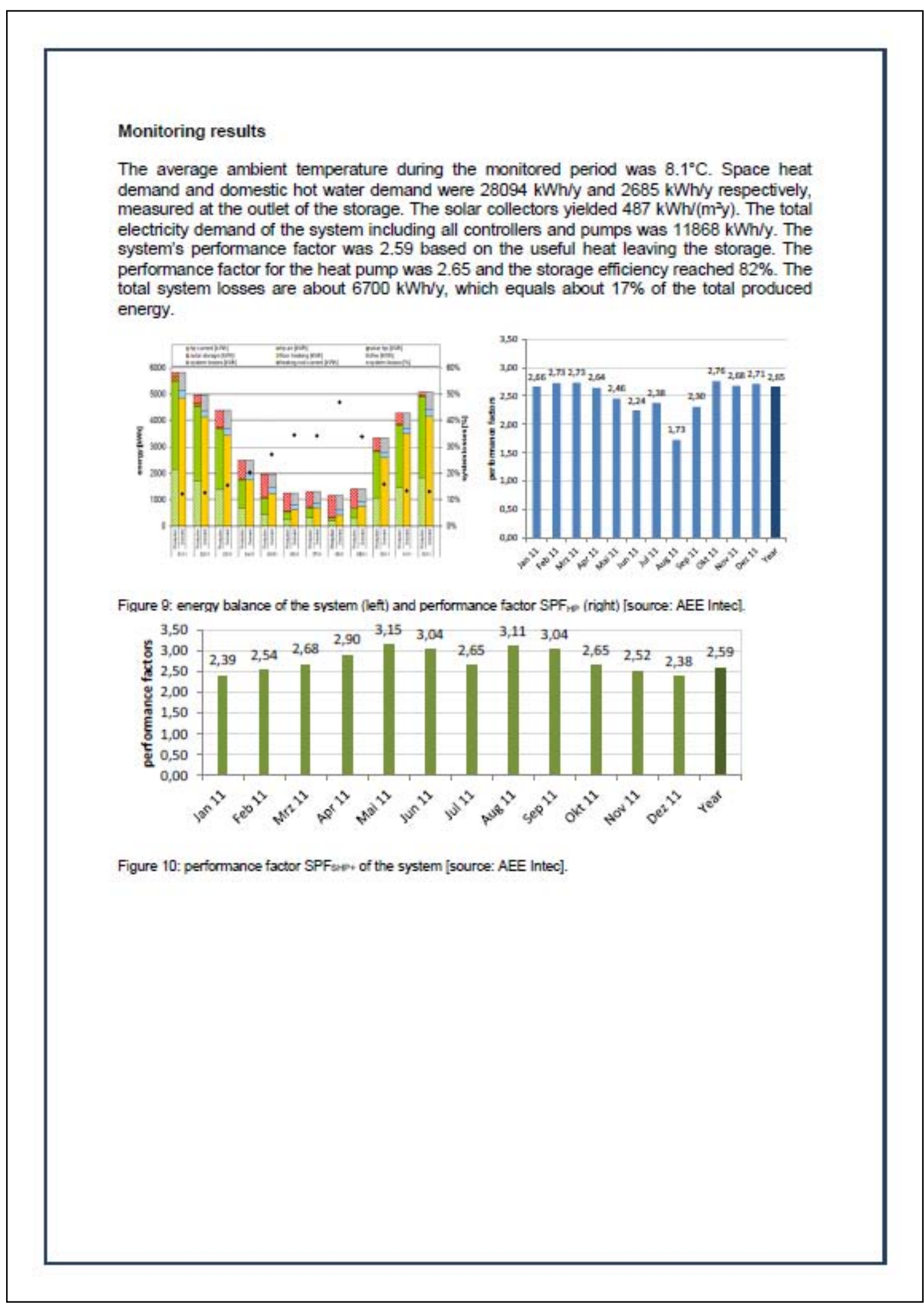




\section{Solar plus Heat Pump system in Dreieich (Germany)}

\section{System description}

A heat pump system with uncovered PVT and ground heat exchanger has been measured over a period of two years starting in March 2009 [5-8]. It consists of a $39 \mathrm{~m}^{2}$ PVT-collector field, a $12 \mathrm{~kW}$ heat pump and a coaxial borehole heat exchanger with a total length of 225 $\mathrm{m}$. The system provides space heat and domestic hot water for a large single family house.

As the thermal PVT-collector yield's impact on the heat pump performance cannot be measured directly, the measured data has been analyzed using a model of the combined solar and ground heat source in a TRNSYS simulation based on measured data.

\section{Technical data}

\begin{tabular}{|c|c|}
\hline Location & $\begin{array}{l}\text { Dreieich, Gemany } \\
\text { Coordinates: } 50.0^{\circ} \mathrm{N}, 8.7^{\circ} \mathrm{E} \\
\text { Elevation: } 140 \mathrm{~m}\end{array}$ \\
\hline Bulding & $\begin{array}{l}\text { Typology: Single-family house (5 people) } \\
\text { Living area: } 380 \mathrm{~m}^{2} \\
\text { Space heating demand: } 66.4 \mathrm{kWh} /\left(\mathrm{m}^{2} \mathrm{y}\right) \\
\text { Domestic Hot Water: } 6.2 \mathrm{kWh} /\left(\mathrm{m}^{2} \mathrm{y}\right)\end{array}$ \\
\hline Heat Pump & $\begin{array}{l}\text { Source: brine (PVT collectors + boreholes) } \\
\text { Heating capacity: } 11.6 \mathrm{~kW} \\
\text { Performance: COP } 4.65 \text { (BOM } 35 \text { EN 255) }\end{array}$ \\
\hline Solar collectors & $\begin{array}{l}\text { Orientation: } 24^{\circ} \text { East } \\
\text { Typology: uncovered PVT collectors } \\
\text { Thermal efficiency: } \eta_{0}=0.56, b_{1}=8.8 \quad W /\left(m^{2} \mathrm{~K}\right), b_{2}=0.55 \mathrm{~J}\left(\mathrm{~m}^{3} \mathrm{~K}\right) \text {. } \\
b_{1}=0.08 \mathrm{~s} / \mathrm{m} \\
\text { Electrical efficiency: } 14 \% \text { at STC conditions } \\
\text { Aperture area: } 39 \mathrm{~m}^{2}\end{array}$ \\
\hline Borehole & $\begin{array}{l}\text { Typology: coaxial } \\
\text { Length: } 225 \mathrm{~m} \\
\text { Depth: } 75 \mathrm{~m} \\
\text { Ground conductivity: } 2.75 \mathrm{~W} /(\mathrm{mK})\end{array}$ \\
\hline Storage & 150 as DHW storage \\
\hline
\end{tabular}

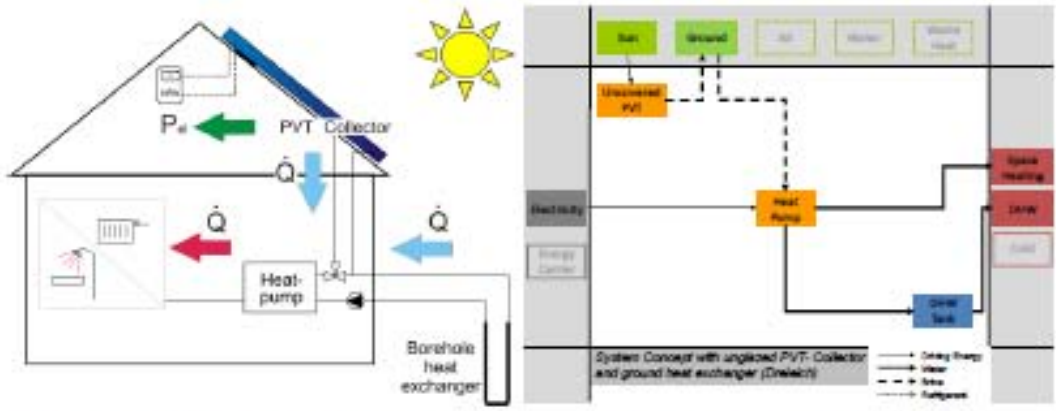

Figure 11: simplified hydraulic scheme (left) and energy flow chart (right) [source: ISFH] 


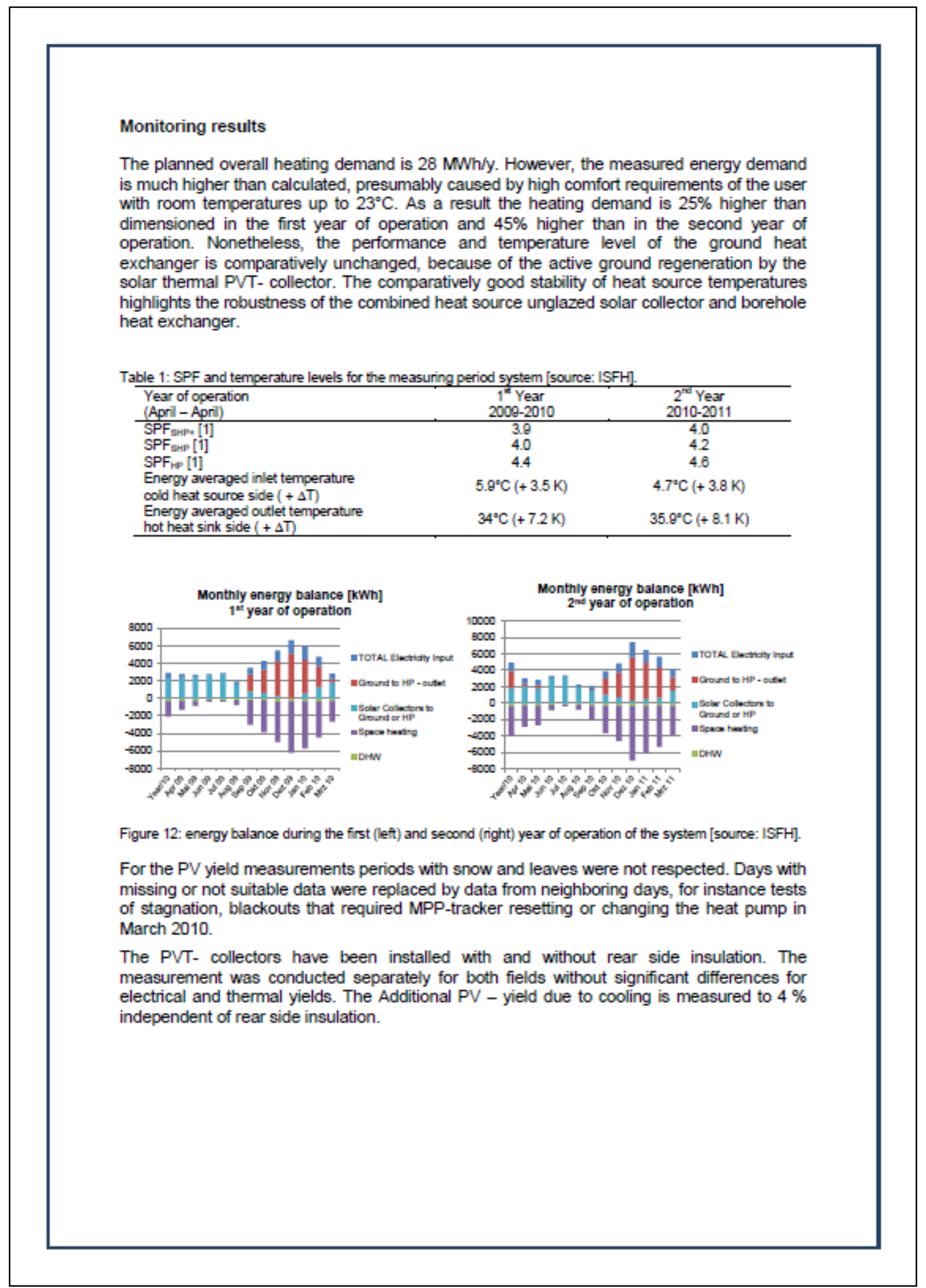




\section{Literature reference}

1. Malenkovic, I., Eicher, S., Bony, J., "IEA SHC Task 44 / HPP Annex 38. Definition of main system boundaries and performance figures for reporting on SHP systems. A technical report of Subtask B. Deliverable B1.1", 2012.

2. Gemperle, S., "Analyse einer solarthermisch unterstützten Luft-WasserWärmepumpenheizung", Bacholararbeit an der Hochschule für Technik Rapperswil HSR, Institut für Solartechnik SPF, 21. Juni 2010, Rapperswil-Jona, Switzerland.

3. Thür A., Vukits M., Becke W., Heinz A., Lerch W. "Ein Jahr Feldmessung von sechs Solar-Kombianlagen mit Wärmepumpen", OTTI - 22. Symposium Thermische Solarenergie, Bad Staffelstein, 2012.

4. Lerch, W., Heinz, A., Thür, A., Vukits, M. "Optimierung von Solar-WärmepumpenKombianlagen anhand von dynamischen Anlagensimulationen", OTTI - 22. Symposium Thermische Solarenergie, Bad Staffelstein, 2012.

5. Bertram, E., Stegmann, M., Scheuren, J., Rosinski, C., Kundmüller, K., "Unglazed

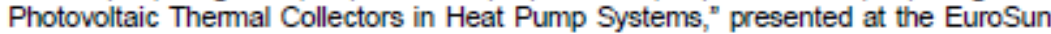
2010 Intemational Conference on Solar Heating, Cooling and Buildings, Graz, 2010.

6. Bertram, E., Glembin, J., Rockendorf G., "Unglazed PVT collectors as additional heat source in heat pump systems with borehole heat exchanger," Proceedings of SHC Conference 2012 in San Francisco, published in Energy Procedia, In Press.

7. Bertram, E., Stegmann, M., Rockendorf, G., "Solarthermie 2000plus: Solare Gebäudewärmeversorgung mit unverglasten photovoltaisch-thermischen Kollektoren, Erdsonden und Wärmepumpen für $100 \%$ Deckungsanteir", Teilprojekt $B$ : Wissenschaftliche Begleitung. Emmerthal: , 2011. avaiable at http-/ledok01.tib.unihannover.de/edoks/e01fb12/684730588.pdf.

8. Stegmann, M., Bertram, E., Rockendorf G., Janßen, S., "Model of an unglazed photovoltaic thermal collector based on standard test procedures," in Proceedings of ISES Solar World Congress, Kassel, Germany, 2011. 
Task 44 / Annex 38 - Participants

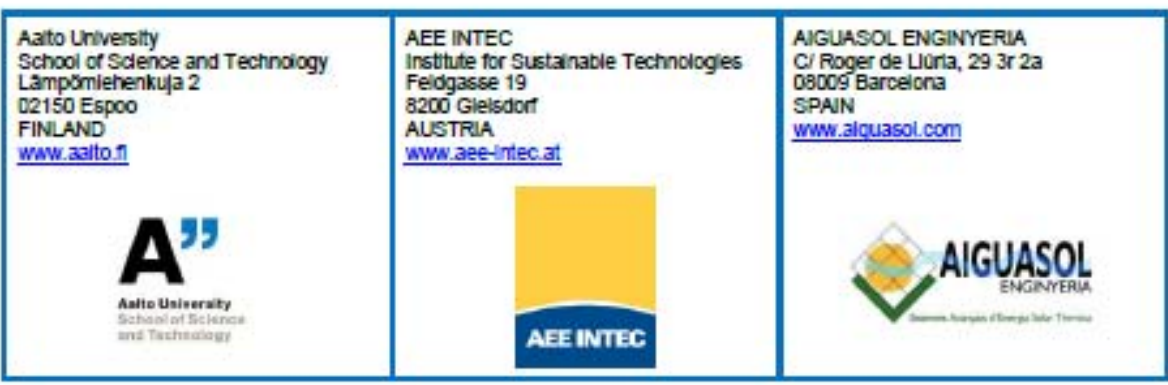

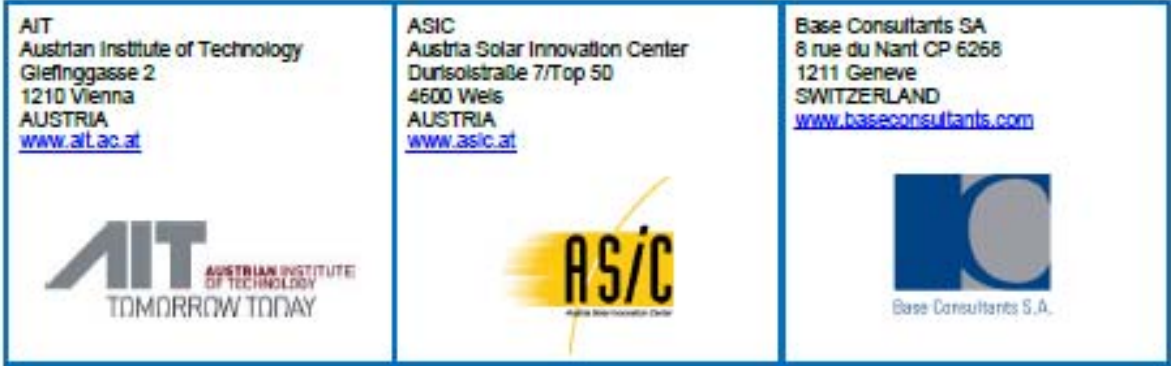

\begin{tabular}{|c|c|c|}
\hline $\begin{array}{l}\text { CEA INES } \\
\text { Institut National de IEnergle Solale } \\
50, \text { Avenue du Lac Leman } \\
73377 \text { Le Bourget du Lac } \\
\text { France } \\
\text { waw. Iten.ft } \\
\text { wawilnes-solalre.org }\end{array}$ & $\begin{array}{l}\text { CENERGIA } \\
\text { Heriev Hovedgade } 196 \\
2730 \text { Helev } \\
\text { DENMARK } \\
\text { www.cenergla,ds }\end{array}$ & $\begin{array}{l}\text { Consolar } \\
\text { Soliare Energlesysteme GmbH } \\
\text { Gewerbestrasse } 7 \\
79539 \text { Lörach } \\
\text { GERIMANY } \\
\text { wur.consolar.de }\end{array}$ \\
\hline
\end{tabular}

\begin{tabular}{|c|c|c|}
\hline $\begin{array}{l}\text { DANISH } \\
\text { TECHNOLOGICAL } \\
\text { INSTITUTE }\end{array}$ & $\begin{array}{l}\text { DTU } \\
\text { Technical University of Dermark } \\
\text { Anker Engelundsve] } 1 \\
2800 \text { Kgs. Lyngby } \\
\text { DENMARK } \\
\text { wWw dtudk }\end{array}$ & 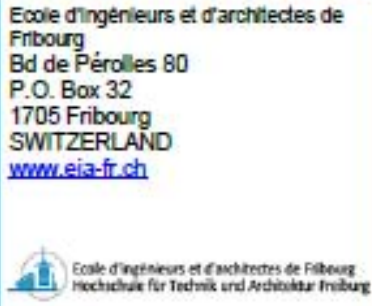 \\
\hline
\end{tabular}




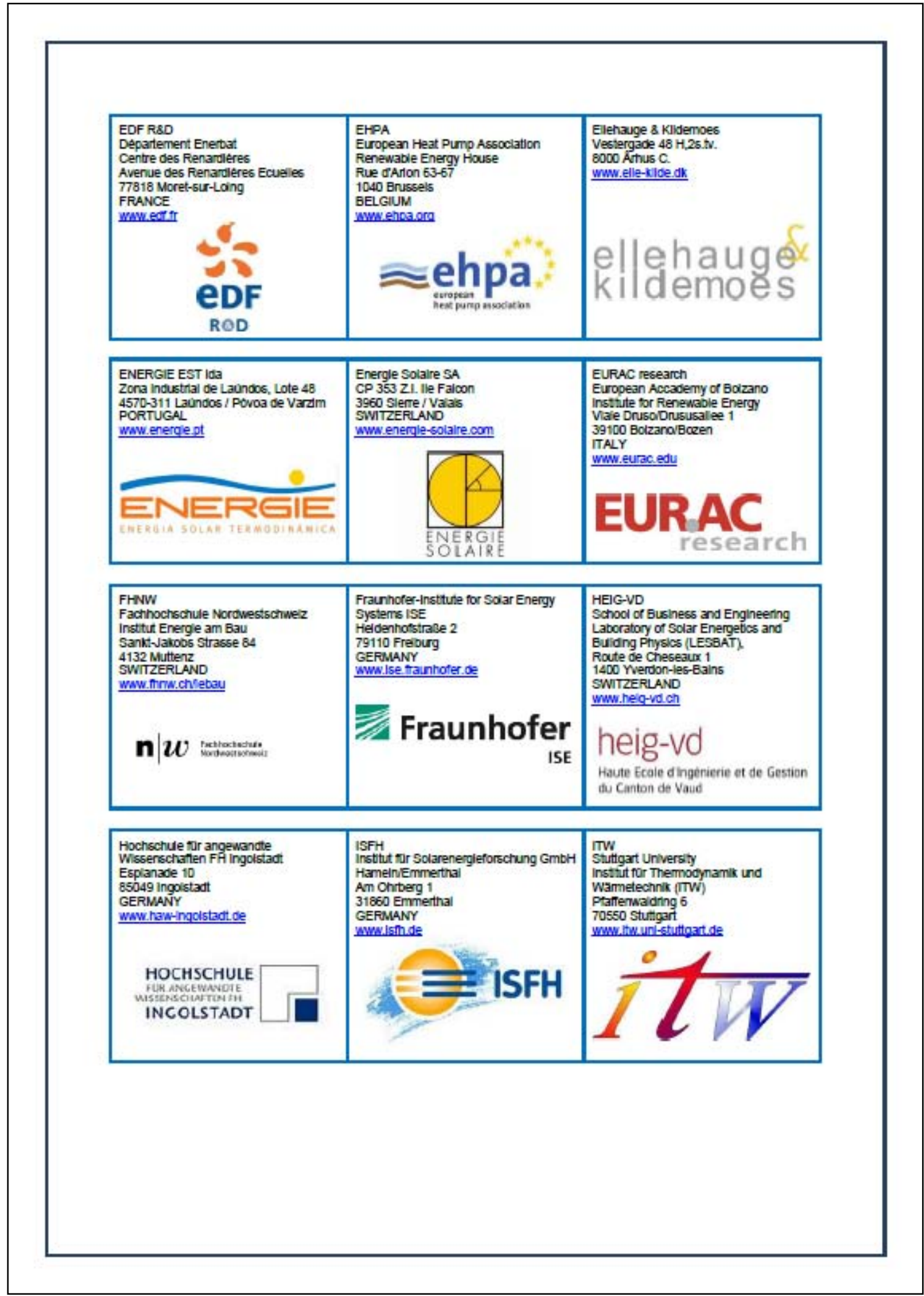




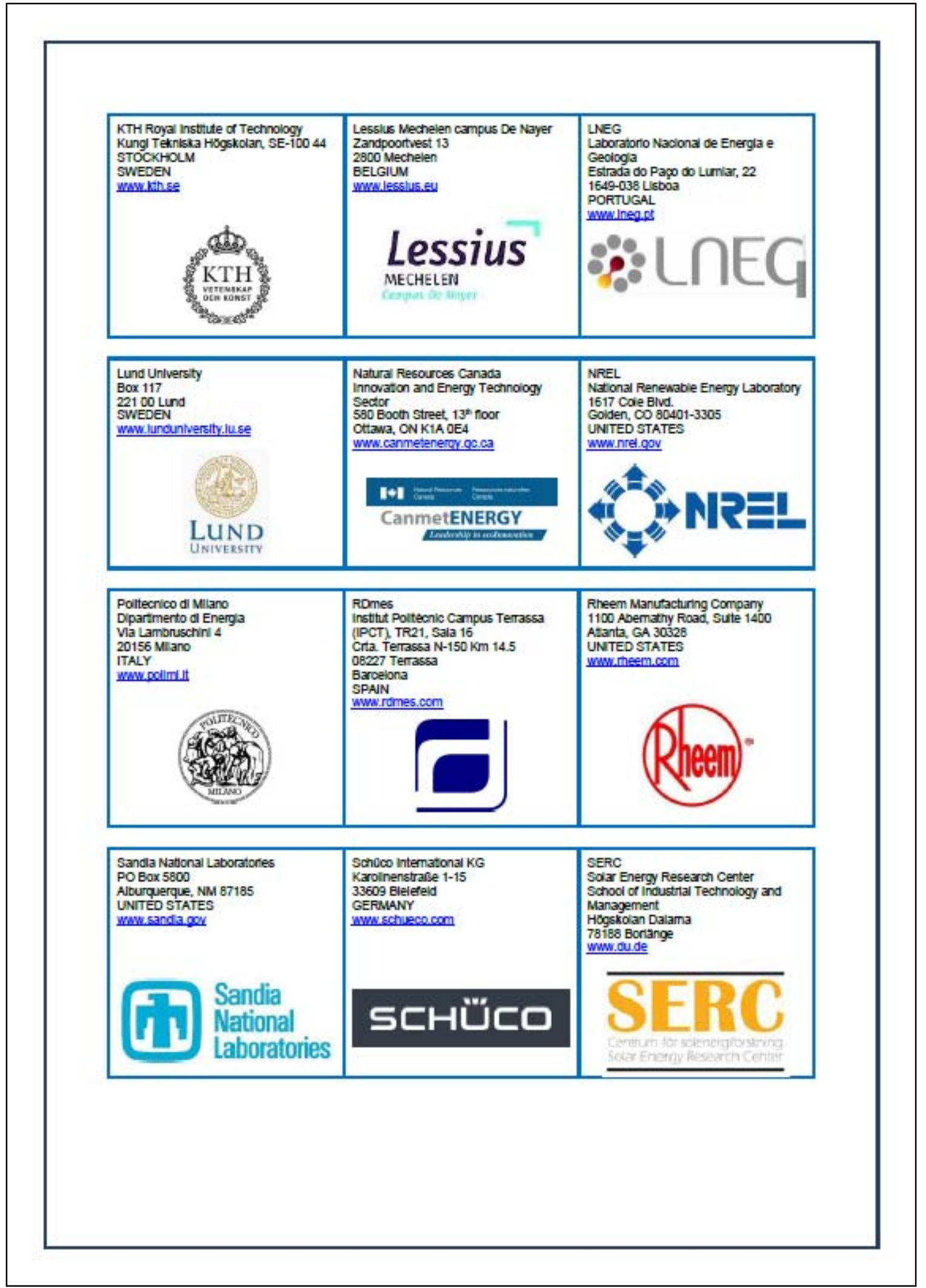




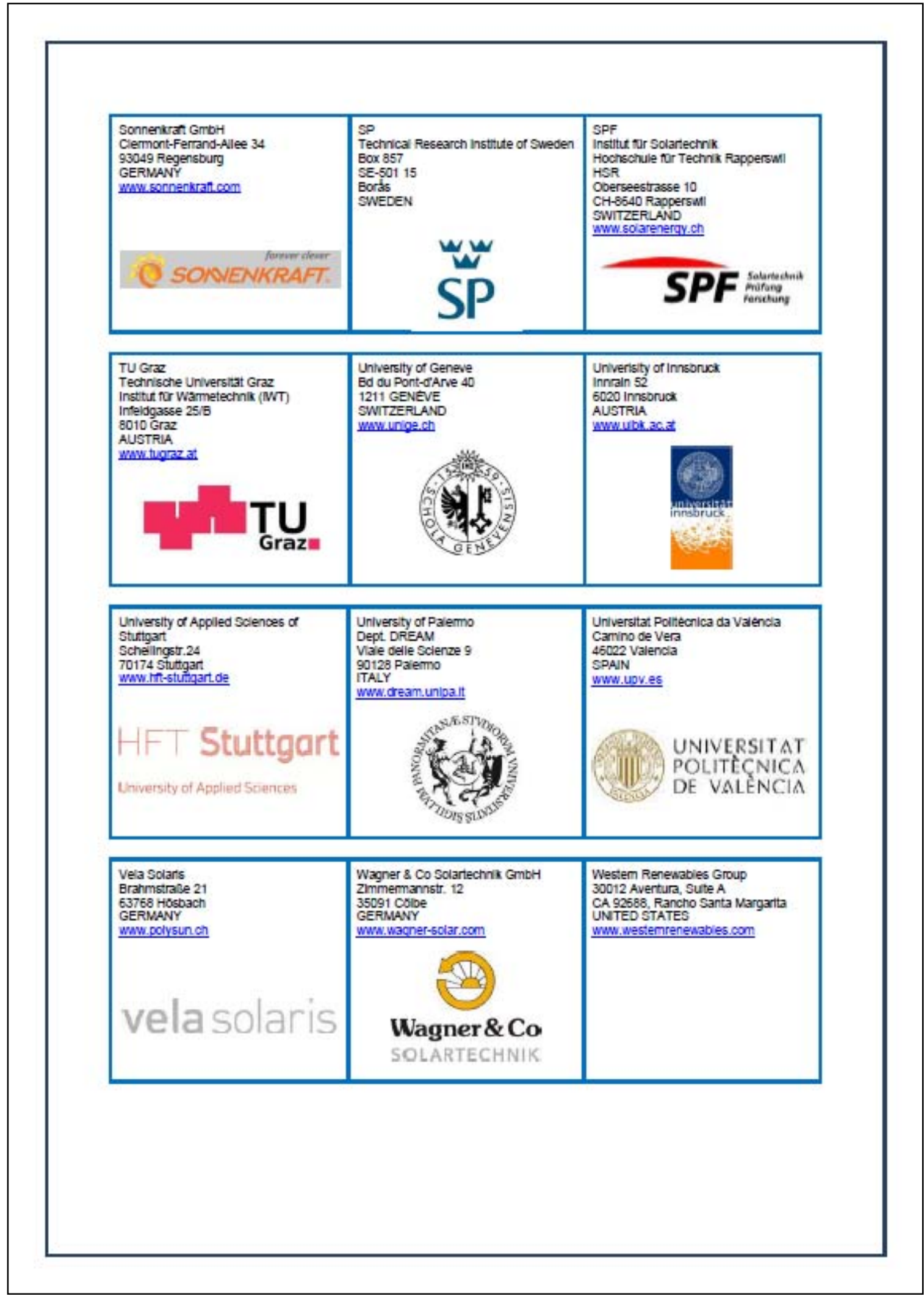




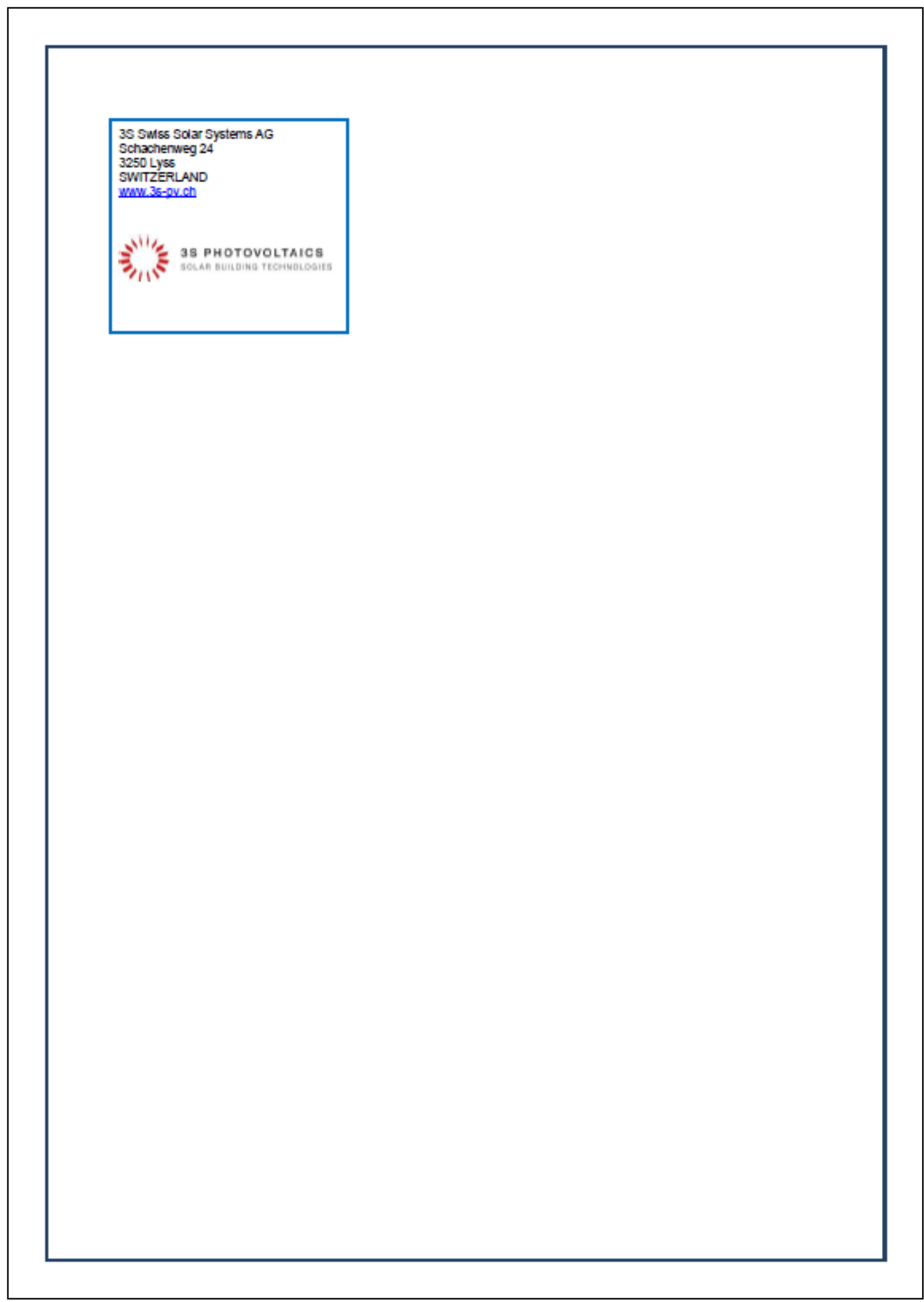

